\title{
Human conditions of insulin-like growth factor-I (IGF-I) deficiency
}

\author{
Juan E Puche and Inma Castilla-Cortázar
}

\begin{abstract}
Insulin-like growth factor I (IGF-I) is a polypeptide hormone produced mainly by the liver in response to the endocrine GH stimulus, but it is also secreted by multiple tissues for autocrine/paracrine purposes. IGF-I is partly responsible for systemic $\mathrm{GH}$ activities although it possesses a wide number of own properties (anabolic, antioxidant, anti-inflammatory and cytoprotective actions).

IGF-I is a closely regulated hormone. Consequently, its logical therapeutical applications seems to be limited to restore physiological circulating levels in order to recover the clinical consequences of IGF-I deficiency, conditions where, despite continuous discrepancies, IGF-I treatment has never been related to oncogenesis. Currently the best characterized conditions of IGF-I deficiency are Laron Syndrome, in children; liver cirrhosis, in adults; aging including age-related-cardiovascular and neurological diseases; and more recently, intrauterine growth restriction.

The aim of this review is to summarize the increasing list of roles of IGF-I, both in physiological and pathological conditions, underlying that its potential therapeutical options seem to be limited to those proven states of local or systemic IGF-I deficiency as a replacement treatment, rather than increasing its level upper the normal range.
\end{abstract}

Keywords: Laron syndrome, Liver cirrhosis, Aging, Oxidative stress, GH/IGF-I axis, Mitochondrial dysfunction, Cellular protection, Growth, Cancer protection

\section{Introduction}

Insulin-like growth factor I (IGF-I) is a 70 aa polypeptide hormone with endocrine, paracrine, and autocrine effects. It shares $>60 \%$ homology with IGF-II and by $50 \%$ homology with proinsulin structures [1].

IGFs were first described in 1957 by Salmon and Daughaday [2] when they noted that direct addition of growth hormone $(\mathrm{GH})$ to costal cartilage from hypophysectomized rats in vitro did not significantly stimulate growth (measured by radioactive sulfate uptake). Consistently, serum from these hypophysectomized rats was also ineffective. However, normal rat serum stimulated the in vitro uptake of sulfate into costal cartilage from hypophysectomized rats. These results demonstrated the existence in serum of a "sulfation factor" that stimulated incorporation of ${ }^{35}$ Sulfate by costal cartilage.

In parallel, Froesch et al. described the non-suppressible insulin-like activity (NSILA) of two soluble serum

\footnotetext{
* Correspondence: iccortazar@ceu.es

Applied Molecular Medicine Institute (IMMA), School of Medicine,

Department of Medical Physiology, Universidad CEU San Pablo, Madrid, Spain
}

components (NSILA I and II) by the fact that they stimulated glucose uptake into isolated rat adipocytes, sharing "insulin-like" activity, while anti-insulin antibodies were not able to abrogate their hypoglycemic effects [3].

At the same time, other investigators found some other roles for these polypeptides. Among all, their mitogenic capability, that moved them to propose the term "fraction with multiplication stimulating activity" [4].

Only when Daughaday et al. pointed out that the sulfation factors were "identical with or very similar to the smaller molecular weight component of the nonsuppressible insulin-like activity" in 1972, a new nomenclature was proposed for these two molecules: somatomedin $\mathrm{A}$ and $\mathrm{C}$, denoting substances under control and mediating the effects of $\mathrm{GH}[5]$.

Finally, a more extensive research on NSILAs/ somatomedins carried out by Rinderknecht and Humbel $[6,7]$ culminated with the discovery that those molecules had identical amino acid sequences to "two forms of an insulin-like hormone whose effects on cell and tissue growth predominate over those on metabolic parameters" [8]. Therefore, accordingly to their structural 
resemblance to proinsulin, they were finally renamed "insulin-like growth factor I and II" (IGF-I and II), molecules that also fulfill all the criteria of a somatomedin: 1) they possess insulin-like activity in the presence of insulin antibodies $[3,9]$; 2) they are sulfation factors $[9,10]$; 3 ) they could act as mitogens [9,11]; and 4) at least, IGF$\mathrm{I}$ is growth-hormone dependent [5].

The consensus about their nomenclature [12] together with the milestone in the discovery of their amino acid sequences, which made possible the subsequent recombinant synthesis [8], opened the door to many new areas of research, and boosted the number of articles from that moment up to more than 32,500 works currently indexed in PubMed.

This historical perspective provides us a list of actions carried out by IGF-I, among others: tissue growth and development, insulin-like activity, proliferative, pro-survival/anti-aging, antioxidant, etc.

As an hormone with a wide range of physiological roles, IGF-I levels must be strictly controlled, as it has been demonstrated from in vivo results: six forms of high affinity IGF binding proteins (IGFBPs 1 to 6), either promoting or inhibiting IGF-I actions; a yearly increasing list of IGFBPs proteases; allelic variations and an alternative splicing are some of the mechanisms by which IGF-I is tightly maintained in a close physiological range $(\sim 286.1 \pm 52.4$ $\mathrm{ng} / \mathrm{mL}$, adults between $21-40$ years old) $[13,14]$.

On the other hand, majority of IGF-I actions are mediated through the union of IGF-I to its putative receptor, IGF-IR, a tyrosine kinase that is one of the most potent natural activators of Akt pathway, involving among others: mTOR, MAPK, GSK3 $\beta$, FOXO, HDM2, Grb2 and Shc systems, all of them closely related with cell survival, growth and proliferation [15-17]. However, IGF-I can also bind to the insulin receptor (with a lower affinity), as a secondary via through which this hormone mediates some of its metabolic functions [6], due to their high homology. Complementarily, insulin can also bind to IGF-IR with a lower specificity than insulin receptor (Figure 1).

Under this scenario, a review about the increasing list of IGF-I roles, both in physiological and pathological conditions, and its therapeutical potential, arises as a promising field of work.

\section{Physiological roles of IGF-I}

IGF-I is a relevant hormone both in embryological and postnatal states. Although it is mainly produced by the liver, virtually every tissue is able to secrete IGF-I for autocrine/paracrine purposes [18].

Pituitary (GH) and liver (IGF-I) establish negative feedback mechanisms common to any other endocrine gland. The pituitary somatotrophs ( $\mathrm{GH}$-secreting cells) are under a delicate controlled balance between stimulatory growth horomone-releasing hormone and inhibitory somatostatin, both generated by the hypothalamus as a result of systemic and cortical neurogenic, metabolic, and hormonal factors [19]. In another hand, IGF-I inhibits GH secretion acting on the hypothalamus by two feedback mechanisms: firstly, inhibiting GH gene expression [20] and secondly by stimulating the secretion of somatostatin $[21,22]$, that inhibits GH production.

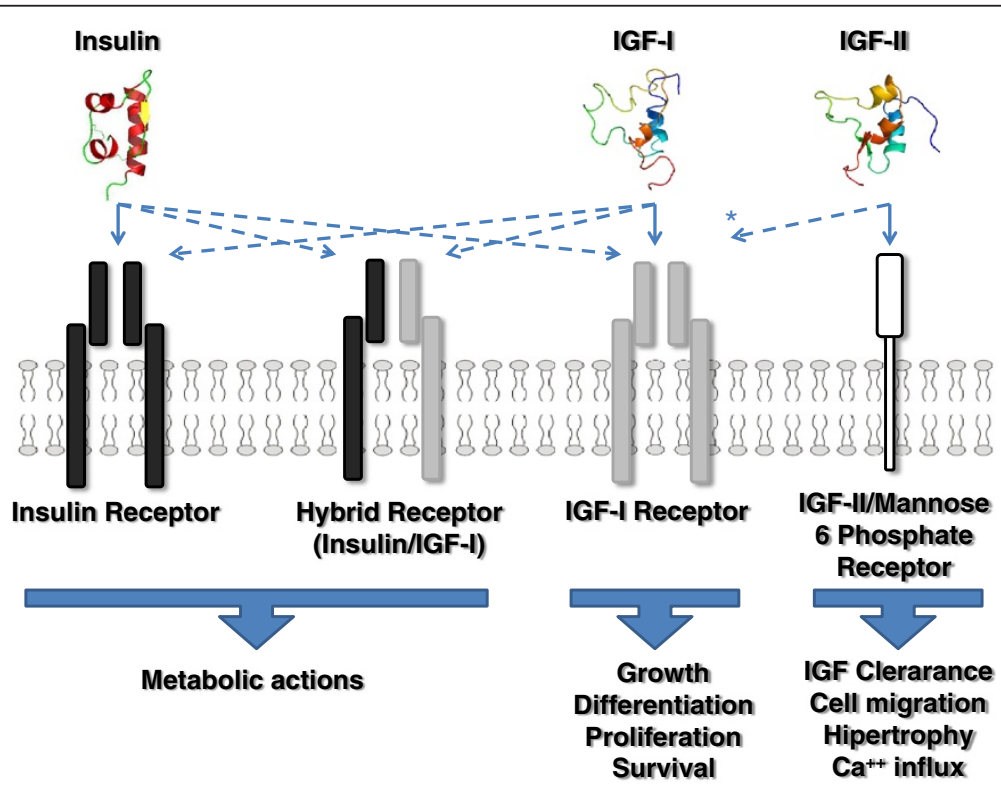

Figure 1 Schematic structures of IGFs and their receptors. Resemblances between Insulin and IGFs allow them to cross-interactions by which IGFs are able to bind to their own receptors (preferently) but also to Insulin receptor (IR) with a lower specificity. The hybrid receptor shares components from both IR and IGF-IR. * IGF-II can also interact with IGF-IR, hybrid receptor and insulin receptor, with a lower affinity. 


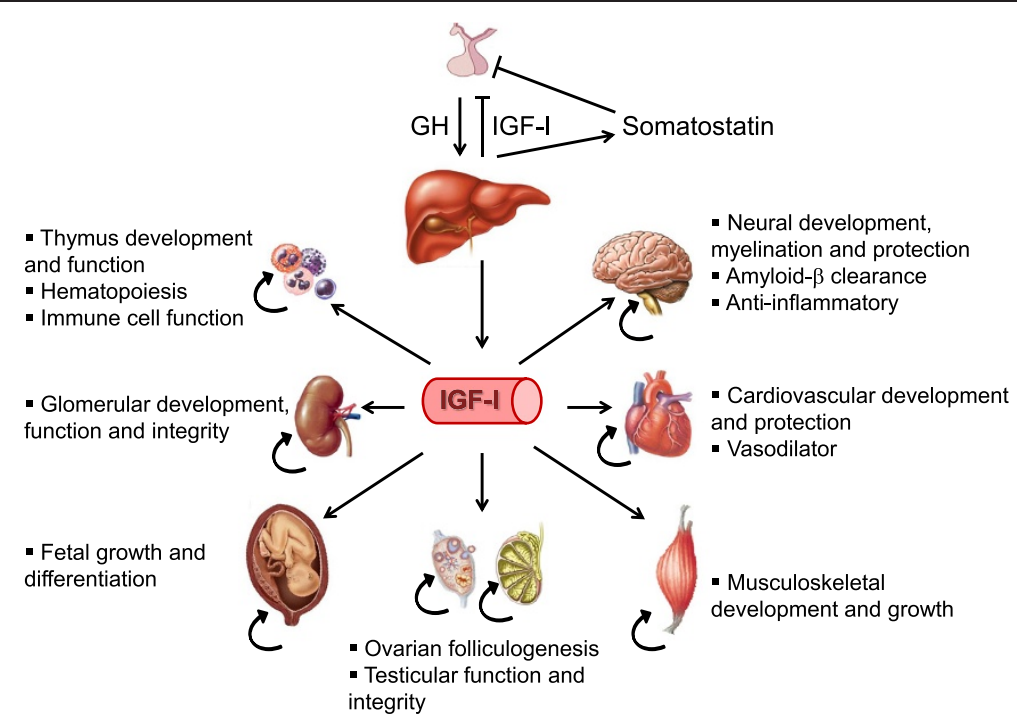

Figure 2 GH/IGF-I axis and targets. Pituitary GH interacts with GH receptors in hepatocytes increasing IGF-I secretion for endocrinological purposes in different organs, although an autocrine/paracrine IGF-I production by those organs is also present.

Secreted GH can exist in both free and bound states by the GHBP (the secondary domain of the GH receptor) [19]. Also, activation of liver GH receptor, promotes IGF-I synthesis which, in turn, is released to the circulation and can be found in its free form but mainly bound to IGFBPs (overall IGFBP-3, which binds $~ 90 \%$ of circulating IGF-I) [23].

The role of IGF-I in physiological conditions is still being uncovered and continuously unfastened from $\mathrm{GH}$ actions as an independent, self-sufficient peptide. For example, it is known that GH and nutrition are the major factors that regulate hepatic IGF-I expression, as well as in other organs $[24,25]$. However, in some other tissues, IGF-I expression appears to be regulated by tissue specific trophic factors, as for example in uterus, where estrogens (and not GH) stimulate IGF-I expression [26], while follicle stimulating hormone is a major IGF-I regulator in ovary [27].

In an attempt to provide a coherent and integrated review of certain physiological conditions where the role of IGF-I has been well established, we have summarized them in this review (cfr. Figure 2).

\section{Body growth}

IGFs have been shown to play a very important role in fetal growth and differentiation [24,28,29], although their pattern of expression and abundance varies among organs. For instance, in fetal liver, kidney and heart are lower than IGF-II, while they progressively increase after birth (as serum IGF-I concentration does). However, expression of IGF-I in fetal lung, muscle, and stomach is higher than it is postnatally [29].
Of interest, while the actions of IGF-I after birth are being continuously recognized, the physiologic role of IGF-II is still poorly understood at this stage $[1,30]$. Interestingly, it was reported that $\mathrm{GH}$ is not required for normal intrauterine growth, a finding supported by evidence that GH deficiency/insensitivity does not associate with a significant reduced size at birth [31-35]. In contrast, inactivating mutations of IGF-I or its receptor, have clearly established that IGF-I is a major regulator of intrauterine growth [36-41]. Thus, these findings suggest that the stimulatory role of IGF-I on intrauterine growth is $\mathrm{GH}$-independent.

With this perspective, Daughaday et al. [5,42] proposed the somatomedin hypothesis for the postnatal growth, where GH stimulated skeletal growth by stimulating liver production of IGF-I, which in turn promotes longitudinal bone growth in an endocrine manner. However, a noteworthy direct action of $\mathrm{GH}$ on bone growth has also been reported $[43,44]$. Nevertheless, the discovery of an extra-hepatic IGF-I production in the following years $[18,45]$, made it necessary to spand the conception of the GH/IGF-I axis, being well accepted nowadays that pituitary GH is able to induce IGF-I synthesis in both liver $(\sim 75 \%)$ and other tissues $[23,46,47]$, which subsequently, is able to act in an endocrine/paracrine/autocrine manner.

So, taking into account all these data, we can conclude that both GH and IGF-I has independent and synergic effects in promoting postnatal body growth. This idea was also confirmed by comparing the weight of transgenic mice with GH receptor inactivation, IGF-I knockout and the double inactivation [36]. As expected, double knockout mice presented a more severe 
reduction in body length than the other two models ( 20\% more).

Finally, GH and IGF-I (both liver/endocrine and locally produced) are essential for normal body growth. The role of other molecules for this control is also important and may increase the complexity in the understanding of these mechanisms. Acid-labile subunit (ALS) and IGFBP-3 are two proteins that bind IGF-I ( $90 \%$ of total serum IGF-I) in a ternary complex which transports and prolong IGF-I half-life in circulation [23]. Although the liver is also the principal source of circulating IGFBP-3 and ALS, other tissues have been proposed to produce these factors $[48,49]$. The importance of IGFBP-3 relies also on its capability to act independently from IGF-I, regulating growth, apoptosis and metabolism of target cells [50-52]. Therefore, the expression of ALS and IGFBP-3 in non-hepatic tissues and possible IGF-I-independent effects of IGFBP-3, should be considered when analyzing findings. To go through IGFBP-3 roles/effects in depth the review by Ohlsson C et al. is recommended [23].

\section{Central nervous system (CNS) development}

Although the action mechanisms of IGF-I in neurons have not been fully elucidated, it has been shown that IGF-I stimulates the autophosphorylation of IGF-IR [53] in a different manner to insulin [54]. Furthermore, as it will be further discussed, we have reported a neuroprotective role for IGFs associated to mitochondrial protection and antioxidant defenses in aging animals [55-58]. Both mechanistic pathways, that may be linked, are currently being studied in more detail.

IGF-I is harmonically produced by peaks that coincide with periods of neuron progenitor proliferation and differentiation, neuritic outgrowth (increasing the number of dendrites, axonal cones, synapse number...) or postinjury conditions [59]. However, the possibility of IGF-I to influence neural stem cells (NSC) is still on debate despite the fact that IGF-I and IGF-IR are expressed in cultured NSC $[60,61]$, and that in response to IGF-I, cultured NSC proceed toward specific lineages, such as neurons [62] or oligodendrocytes [63].

Interestingly, not only neural-produced IGF-I is involved in these processes. It was first reported 20 years ago that systemic IGFs could cross the blood-brain barrier (BBB), when labeled IGFs were infused into the common carotid arteries of adult rats, and they were later on detected in the choroid plexus, median eminence, brain arterioles, and parenchyma [64]. In fact, this work was based on previous data confirming the presence of IGF-I receptors in brain capillary endothelial cells (which constitute the BBB), and their role in internalizing IGFs to the CNS from the circulation $[65,66]$. A more recent work by Torres-Aleman's group, elegantly demonstrated that this process is initiated by the release of glutamate at active regions, triggering two secondary processes: a vasodilation to increase local serum IGF-I availability and an increased activity of matrix metalloprotease 9, together with cleavage from IGFBP-3. The combined action of these events results in an increased local availability of free serum IGF-I, which is then transported by transcytosis using an endothelial transporter (lipoprotein related receptor 1) dependent mechanism [67]. This research may shed light on previous data identifying liver-derived IGF-I as one of the main factors in regulating the clearance of brain amyloid- $\beta$ (A $\beta$ ) levels [68] and its potential implications in Alzheimer's Disease (what will be further discussed in III.4.3.). However, it is noteworthy that there is no significant correlation between serum and cerebrospinal fluid IGFs concentrations [69] and therefore, it seems that systemic IGFs are not a major source of IGFs for CNS.

On the other hand, little is known about those factors and mechanisms that regulate IGF-I expression in the brain, but there is evidence, however, that growth factors (i.e. $\mathrm{GH}$, epidermal growth factor, basic fibroblast growth factor) [70-72], nutrition [73,74], and injury (hypoxic/ischemic, stereotactic, electrolytic and cryogenic injuries, as well as induced demyelination and experimental autoimmune encephalomyelitis) [75-81], influence its in vivo brain expression. Nevertheless, IGF-I mRNA abundance is reduced in the brain of hypophysectomized rats and, intracerebral infusion of GH restores IGF-I mRNA to $80 \%$ of normal levels [70], which points out that GH has a clear role in modulating brain IGF-I.

Additionaly, IGF-I may promote proliferation and/or survival of oligodendrocytes and their precursors, but it also could be involved in the modulation of BBB permeability [81]. The latter would limit accessibility of $\mathrm{T}$ lymphocytes and soluble destructive immune factors to the brain. Other possibilities are also plausible, as for instance, IGF-I may influence the peripheral immune reaction, what in turn could reduce CNS inflammation, demyelination, and BBB permeability [82]. These findings, taken together with the neuroprotective actions of IGF-I [55,56], suggest that astrocytes are relevant in ameliorating brain injury.

In another hand, in vivo experiments with transgenic mice have clarified some aspects about the topic. Transgenic $(\mathrm{Tg})$ mice that overexpress IGF-I in the brain exhibit postnatal brain overgrowth without anatomic abnormality (up to $85 \%$ ) via an increase in cell number [83] and myelination [84]. A complementary experiment [83] excluded the possibility of $\mathrm{GH}$ in directly promoting these effects, since GH-overexpressing $\mathrm{Tg}$ mice did not exhibit those changes. However, as stated before, a role for GH in brain growth cannot be underestimated, since GH-deficient mice have significantly smaller brains than normal mice 
[23]. Consistently, transgenic mice with ablated IGF-I expression barely survive postnatally. Survivals have very small brains (-60\% of normal size) but remain morphologically normal [85]. These brains are characterized by a paucity of white matter owing to markedly decreased myelination [86] and an apparent decrease in the number of axons [85].

These IGF-I actions, taken together with its neuroprotective effects following CNS and peripheral nerve injury, suggest that it may be of therapeutic benefit in a wide variety of disorders affecting the nervous system.

\section{Liver regeneration}

The liver is the main source of circulating insulin-like growth factor I, accounting for $\sim 75 \%$ of circulating IGF-I levels secondary to the $\mathrm{GH}$ stimulation on hepatocytes $[23,46,47]$. Of interest, although liver-derived IGF-I has endocrine effects on extrahepatic tissues, there are only few data regarding local effects of this hormone in the liver [87] probably due to the very low amount of IGF-I receptors on the hepatocytes membrane $[46,88,89]$. However, there are IGF-I receptors on the nonparenchymal cells $[89,90]$ and it has been reported that IGF-I stimulates both DNA synthesis $[91,92]$ and the production of hepatocyte growth factor (HGF) in hepatic stellate cells in vitro [87].

The lack of IGF-I receptors on hepatocytes would also mean that liver-derived IGF-I would be unable to stimulate liver growth during adulthood. Accordingly, mice with liver-specific IGF-I deficiency, instead of displaying decreased hepatic growth, showed disproportionally large livers, likely due to direct stimulation by an unsuppressed $\mathrm{GH}$ secretion $[47,93]$. In line with this finding, $\mathrm{GH}$ receptor deficient mice have reduced relative liver weight [94], and transgenic mice overexpressing $\mathrm{GH}$ presented disproportional growth of the liver, whereas this is less apparent in mice overexpressing IGF-I $[95,96]$.

Nevertheless, during liver regeneration, where it is required an explosive burst of hepatocyte renewal (i.e. after partial hepatectomy), IGF-I may play a role in supporting hepatocyte proliferation and accelerating DNA synthesis $[97,98]$, together with IL-6, TNF- $\alpha$, HGF and TGF- $\alpha /$ EGF $[99,100]$. It remains unknown why IGF-I stimulates liver regeneration more effectively than growth of intact liver.

\section{Gametogenesis}

\section{Ovarian folliculogenesis}

The process of folliculogenesis can be divided into three developmental phases: I) preantral follicle growth: primordial to primary follicle transition, and formation and growth of secondary follicles; II) basal antral follicle growth: antrum formation and development of early antral follicles to the gonadotrophin-dependent stage; and
III) terminal antral follicle growth: development of antral to preovulatory follicles [101].

The involvement of the IGF system as intraovarian regulators of folliculogenesis has been intensively studied in a variety of mammal species, and it is now established that the ovary is a site of IGF-I gene expression and reception [102]. However, this huge amount of data could be somehow distractive since different species may produce distinct IGFs (or their relative binding proteins and receptors) at different stages of follicular development. For this reason, in this review, we will focus on murine and primate data.

In primate, mRNA expression patterns of IGF-I and its putative receptor have been deeply studied during folliculogenesis. IGF-I is expressed in primordial follicles, primary follicles, secondary follicles and growing antral follicles (oocyte and theca), but not in preovulatory follicles (mural granulose and theca) [101]. Of interest, IGF-IR mRNA is temporally consistent with the IGF-I expression, except from the mural granulose cells, where IGF-IR production is preserved, suggesting a paracrine/endocrine dependence for the IGF-I effects at this level [101].

The lack of information regarding the role of IGFs in a specific time point of human folliculogenesis, hinder its correlation with the expression patterns of IGF-I. Fortunately, murine models provide us a useful tool to elucidate its possible implications. This approach suggest that IGF-I may play a role at different stages of follicular development: a) initiation of growth of the primordial follicle; b) at a secondary follicle stage, IGF-I may be involved on induction of FSH-R expression on granulose cell and their differentiation, theca cell survival and cortical granules formation in oocytes [103-106]; and c) at antral follicular stage, IGF-I may increase follicle sensitivity to gonadotrophin, oocyte maturation and LH-R expression in granulose and theca cells enhancing their proliferation and steroidogenic activity [107-111]. In humans, IGF-I also stimulates vascular endothelial growth factor production by granulose cells [112].

Despite recent progresses, the precise mechanisms underlying ovarian follicular growth are not yet fully elucidated. In most mammalian species studied, although $\mathrm{GH}$ and IGFs do not appear to be required for primordial to primary follicles transition, they are responsible for promoting secondary follicle growth and antrum formation. In brief, GH enhances the development of small antral follicles to the gonadotrophin-dependent stages and stimulates oocyte maturation, whereas IGFs increase granulose cell proliferation, steroidogenesis and oocyte growth in most mammalian species [101].

\section{Testicular function}

Although it is well established that testicular function is mainly controlled by the gonadotropins LH and FSH 
$[113,114]$, there is now considerable evidence pointing to locally produced factors as important key regulators of testicular function [115]. Among those, IGF-I has been reported to be a potent candidate due to its para/autocrine functions. Immunostainable IGF-I has been found in adult human testes [116]. Cultures of Sertoli and Leydig cells from adult rats and immature pigs secrete immunoreactive IGF-I into the medium, and this secretion is enhanced by FSH (Sertoli cells) or LH (Leydig cells) $[117,118]$. IGFIR has also been found on human, pig, and rat Leydig cells [119-121], where it enhances the differentiated functions of Leydig cells [122,123].

The crucial role of IGF-I in the development and function of Leydig cells was obtained from studies in IGF-I knockout mice [124]. The testes of these animals were reduced in size and although epididymides were overall nearly allometric to the reduced body weight, the distal regions of the duct, vas deferens, seminal vesicles, and prostate were vestigial. These transgenic mice showed significantly reduced plasma testosterone levels (18\% of normal) [124] and the IGF-I deficiency was correlated with an ultrastructural analysis of mutant Leydig cells revealing a significant developmental delay, with fewer and smaller Leydig cells than normal. Importantly, it is noteworthy that those reduced testosterone levels in serum were inadequate for perinatal androgenization. And secondly, androgen deficiency in the mutants can be correlated with an apparently retarded differentiation of Leydig cells (in concrete, their second phase) [124]. In vitro studies also suggested a relationship between IGF-I and LH-androgen production in rodents [125], through a direct effect on Leydig cells.

Consistently, a large number of studies have previously suggested that the IGF system is involved in mammalian reproductive functions [108,126,127]. First, it has been emphasized the importance of insulin receptor family for the induction of testicular differentiation by Srydependent processes [128]. In addition, IGF-I regulates the expression of key steroidogenic enzymes during prenatal development, which in turn lead to establishment of the male phenotype and fertility [129]. Moreover, male gonads cultured in the presence of IGF-I increased testosterone production during testicular development [130]. Postnatally, in vitro studies have also demonstrated that the IGF-I regulates the expression rate of genes encoding steroidogenic enzymes that involved in the biotransformation of steroid hormones in the testis [131-133]. Secondly, a role for IGF-I on sperm number has been reported since in IGF-I deficient mice there is a dramatic reduction of sperm number [124]. Moreover, the vast majority of these males that were caged with wild type females did not exhibit mating behavior.

In another hand, it is notable that the role of $\mathrm{GH}$, if any, on the regulation of intratesticular IGF-I may not be significant, since $\mathrm{GH}$ receptor gene may not be expressed in the testis $[134,135]$ and GHI animals are fertile (normal steroidogenesis and spermatogenesis) $[136,137]$. Interestingly, despite $\mathrm{GH}$ deficiency and low serum IGF-I concentration, they exhibit normal levels of testicular IGF-I [119]. Thus, in addition to being apparently $\mathrm{GH}$-independent, the testicular functions of IGF-I seem to be served by its local production (autocrine/ paracrine action) without a major endocrine contribution by the circulating form of this factor.

\section{Kidney development and function}

Several lines of evidence support the role of the GH/ IGF-I system in normal kidney development and function. IGFs, IGFBPs and IGF receptors (along with GH receptors) are all expressed in specific locations along the nephron, suggesting that IGFs have paracrine and autocrine actions at these sites [138,139].

Both IGF-I and the IGF-IR are expressed in glomerulus development being their patterns of expression disrupted in animal models and in human examples of renal disease [140]. Indeed, it has been demonstrated a role for IGF signaling in maintaining glomerular integrity, by preserving podocytes and the glomerular basement membrane from damage. Consistently, IGF-I administration to rodents increases kidney growth, renal blood flow and glomerular filtration rate (GFR) $[138,141,142]$, and similarly, GH and IGF-I also increase renal blood flow and GFR in humans [143], suggesting that IGF-I may be a physiologic regulator of renal function.

Furthermore, a possible role for the IGF system in compensatory renal growth was proposed since renal IGF-I levels are increased in the remaining kidney following uninephrectomy and compensatory renal growth [144] in an age-dependent manner [145]. However, by using IGF-I deficient mice, it has been recently reported that uninephrectomy in these mice induces a significant and proportional increase in renal mass, as compared to normal mice, despite markedly decreased kidney IGF-I levels and no significant changes in receptor phosphorylation [146]. Therefore, the implications of IGF-I in this process may be elucidated in following years.

\section{Cardiovascular development}

Cardiovascular system is an important target organ for GH and IGF-I actions. There is evidence that IGF-I and its receptor are expressed in the myocardium and both aortic smooth muscle and endothelial cells [45,147-149], being all of them more sensitive to IGF-I than to insulin $[150,151]$. In addition, cardiac IGF-I production increases in response to $\mathrm{GH}$ [45]. Consequently, there are different possibilities of direct actions of $\mathrm{GH}$ as well as endocrine or autocrine/paracrine effects of IGF-I on the cardiovascular system. 
Previous studies indicate that IGF-I is a potent vasodilator [152], and that this effect may be partly mediated by increased NO release from the endothelium [153,154]. Accumulating evidence would also suggest that insufficient IGF-I levels play a role in vascular diseases such as atherosclerosis and restenosis [155], what will be discussed in further sections (cardiovascular diseases).

\section{Immune modulation}

The potential relationship between immune function and growth factors such as IGF-I has remained poorly characterized until recently. However, the realization that diverse regulatory pathways often converge, motivated a number of studies that eventually demonstrated the importance of GH, IGF-I, and IGF-IR in many processes of immune function [156].

Complex interactions between cytokines and growth factors, including IGF-I, has been properly reviewed by O'Connor et al. [157]. In brief, pro-inflammatory cytokines seem to damp several components of the IGF-I pathway. Many of the cytokines share common signaling components, such as Erk1/2 MAPK.

The role of IGF-I on thymus development and function, hematopoiesis and immune system reconstitution is well documented [158-161].

The role of IGF-I on different immune cell lineages has also been reported. Both IGF-I plays important roles in $\mathrm{T}$ lymphocytes development and function. Specifically, IGF-I can increase the number of $\mathrm{CD} 4{ }^{+} \mathrm{CD} 8^{+}$immature $T$ cells in rat thymus and spleen [162], promotes $\mathrm{T}$ cell survival [163], proliferation, chemotaxis and maturation, and blocks spontaneous and induced programmed cell death $[163,164]$, although it has also been reported to block IL-2-dependent lymphocyte growth and function [165]. The possibility for IGF-I to determine how T-cell compartments are filled throughout life remains an open question. However, given the importance of IL-7 in that process and how IGF-I potentiates the actions of IL-7 in pro-B cell expansion [166], a similar influence on $\mathrm{T}$ cells seems likely.

Aging rodents exhibit diminished responsiveness to pathogens. This shift is associated with reduced cellularity and significant thymus involution $[167,168]$. As will be further discussed in section "Aging and age retaled diseases", IGF-I and GH levels also decrease with aging (somatopause) [169], reason why a potential strategy for reversing these senile changes in thymic vitality may involve administration of either GH or IGF-I, which have been examined for their potential to expand T-cell populations in animals [170].

B cells play diverse roles in immune function by virtue of their further differentiation into immunoglobulinsecreting plasma cells, generation of cytokines, and their importance in antigen presentation. IGF-I has been reported to drive B-cell differentiation, to enhance IL-7dependent B-cell proliferation in parallel with c-kit ligand [171], as well as to potentiate IL-7 promotion of pro-B-cell expansion [166]. When administered in vivo, IGF-I also enhances the population of intrasplenic B cells through increased proliferation of mature cells $[172,173]$ together with an influence on antibody expression and class switching by plasma cells [174].

Human macrophages and granulocytes are also sensitive to IGF-I by displaying IGF-IR [156]. It was documented that IGF-I attenuated spontaneous apoptosis in these populations [175].

Finally, neutrophils seems to be a potential target for IGF-I actions, since it was able to delay Fas-mediated apoptosis through the PI3K pathway. Moreover, this effect was conserved even in the presence of pro-apototic cytokines, suggesting that it may play a dominant role, even within the context of an active inflammation [156].

\section{Conditions of IGF-I deficiency}

An increasing list of animal models has been reported highlighting the role of this molecule in many different organs and systems. In this review, we will focus on the best characterized models of IGF-I deficiency, where the substitutive therapy may be an effective strategy.

\section{Intrauterine growth restriction (IUGR)}

Fetal growth is a complex process involving maternal, placental, and fetal factors from genetic, environmental, and nutritional nature. Intrauterine growth restriction is an important obstetric issue affecting $\sim 5 \%$ of pregnancies and refers to a fetus that has not reached its growth potential [176]. The growth-restricted fetus/newborn is characterized by an increased fetal and neonatal mortality and morbidity $[177,178]$ and an increased risk of clinical disorders in adult life, such as cardiovascular disease, diabetes and obesity $[179,180]$.

In the prenatal period, differences between $\mathrm{GH}$ and IGF-I are clearly shown. Whereas GH insensitivity, both in humans and in transgenic mice, have only mild retardation of growth at birth as previously stated [31-35], IGF-I deficiency in gestational state reveals serious postnatal growth retardation, as has been reported both in humans and in transgenic animal models of IGF-I deletion [36-40]. Interestingly, in contrast to growth hormone insensitivity (GHI), the IGF-I deficient animals are neurologically impaired, as was also reported in a single patient with a defect in the IGF-I gene [40]. Thus it appears that IGF-I is necessary for normal brain development in uterus while $\mathrm{GH}$ insensitivity may be recovered by an intrauterine $\mathrm{GH}$-independent production of IGF-I [181,182].

Fetal progress is widely controlled by the oxygenated blood reaching the uterine circulation, the placental 
integrity and function, and the fetus ability to get the required nutrients [183]. It has been estimated that progenitor's genes account for only $20 \%$ of the variation of human birth weight. Nevertheless, majority of the variation (62\%) is due to the intrauterine environment [184]. Placentas from IUGR pregnancies have been shown to have poor invasion of the trophoblastic cells into the maternal decidual tissues, particularly the maternal spiral arteries $[185,186]$. Studies into the pathological process of IUGR have pointed to an abnormal placental function as a common mechanism [187]. However, it is known that the placental dysfunction is often gradual and it can occur much earlier than any demonstrable IUGR [188], thus difficulting the resolution of this hypothesis.

In the same way, IGFs control growth directly, and circulating IGF-I appears to be virtually independent of fetal GH secretion [182]. However, under this condition, placental growth hormone may take this role as the prime regulator of maternal serum IGF-I during pregnancy [189], being of particular interest the positive expression of IGF-IR in placenta [190] and the lower expression of placental-derived IGF-I during IUGR [191]. In general, endocrine milieu of the human fetus with growth retardation is also characterized by low circulating levels of insulin, IGF-I, IGF-II, and IGFBP-3, and high levels of GH and IGFBP-1 [185,192,193]. At this point, an elegant study in zebrafish demonstrated that knockdown of IGFBP-1 significantly alleviated the hypoxia-induced growth retardation and developmental delay. And consistently, overexpression of IGFBP-1 caused growth and developmental retardation under normoxia conditions [194].

In the last years, it is being proposed a role of fetal programming for an altered GH/IGF axis in IUGR, constituting the so-call Thrifty Phenotype Hypothesis [185], with an already proven inverse association between IGFI levels at 9 months and 17 years. Under this perspective, GH/IGF-I axis may be programmed early in life. This fetal programming could be involved in, at least, two pathological conditions in later life, as insulin resistance and hypertension. Firstly, children with IUGR show an impaired GH/IGF-I axis, which might be contributing to reduced insulin sensitivity and IGF-I resistance, as higher basal and GH-induced IGF-I levels are required to achieve a growth velocity similar to that of other children, what secondarily leads to a compensatory hyperinsulinemia to counteract insulin antagonistic effects of $\mathrm{GH}$ [195] and, an impaired regulation of glucose transporter- 4 expression by insulin in muscle and adipose tissue [196].

In another hand, fetal responses to IUGR-related hypoxia include downregulation of insulin, IGF-I, and IGF-II and increased expression of inhibitory IGFBPs. Hypoxia also activates the hypothalamo-pituitary-adrenal (HPA) axis, raising plasma levels of adrenocorticotropic hormone and cortisol, another mechanism that regulates IGFBP expression [197]. Moreover, as previously stated, kidney growth is under IGF-I control; and a reduced IGF action, parallel to increased cortisol levels, results in a smaller number of glomeruli [198]. Alterations in the renin-angiotensin system are also frequent, probably downstream to activation of the HPA axis. These changes together with compensatory responses for the reduced kidney function probably account for the predisposition to adult hypertension.

\section{Laron syndrome (LS)}

In 1966, Zvi Laron et al. described the first condition of IGF-I deficiency as a new type of dwarfism indistinguishable from genetic isolated GH deficiency, but with unexpected high serum GH levels $[199,200]$ and inability to synthesize IGF-I and other related molecules, as IGFBP3 [34,35,201]. This heterogeneous condition was finally named as Laron Syndrome or primary Growth Hormone insensitivity (GHI), and it includes: $\mathrm{GH}$ receptor deficiency (the most common), GH-GH receptor signal transduction defect, IGF-I synthetic defect, IGF-I receptor deficiency and IGF-I/IGF-I receptor signal transduction defects.

Epidemiologically, this pathological entity is closely related to an ethnic origin ( $>90 \%$ of cases) [19]. Clinically, overall growth in uterus is slightly shorter at birth in LS $(42-47 \mathrm{~cm})$ than in healthy babies $(49-52 \mathrm{~cm})$, suggesting a potential role of IGF-I in controlling intrauterine linear growth [34] as will be discussed ahead. This condition is more dramatic throughout childhood, where both skeletal maturation and organ growth are retarded $[19,34,202]$ probably due to a lower impact of GH on gestational growth as compared to IGF-I [31-40]. These growth abnormalities in LS patients without IGFI substitutive treatment includes postnatal average growth rates of one-half the expected during the first years of life [19], a small brain (with prominent forehead, reduced vertical dimension of the face and hypoplasia of the midfacies and the nasal bridge), a small heart and acromicria [203] together with underdevelopment of the muscular system that delays walking in three-fourth of patients [204,205], osteopenia at all stages (despite normal sex hormone status) with increased occurrence of avascular necrosis of the femoral head [206], impair and weaken skin, hair and nail growth [207], blue sclera due to the decreased thickness of its connective tissue, allowing visualization of the underlying choroid [205], a puberty delay from 3 to 7 years [206], retardation in the maturation of dentition [206] and high-pitched voice [208]. Of interest, normal reproductive function and behavior are widely preserved [202]. 
This condition of IGF-I deficiency highlight the critical role of IGF-I on brain development and function, as also will be stated in section "Neurodegenerative diseases".

Animal models of GHI are available since 1997 [31], helping us to better understanding the patho-physiological changes and potentially improved strategies for treating these patients. Nowadays, this is the unique condition of IGF-I deficiency where rhIGF-I is approved (as will be stated in "Current therapeutic options" section).

\section{Chronic liver disease}

Cirrhosis is a consequence of chronic and diffuse liver disease characterized by replacement of liver tissue by fibrosis, necrosis and regenerative nodules, leading to loss of functional liver mass. Cirrhosis is most usually caused by alcoholism, hepatitis B and C, and fatty liver disease, among other possible causes [209].

Most common complications of advanced cirrhosis include jaundice and coagulopathy from hepatocellular insufficiency, gastrointestinal bleeding from esophageal varices, ascites, hepatorenal syndrome, spontaneous bacterial peritonitis, liver-related encephalopathy, and malnutrition [209]. Although survival in patients with compensated cirrhosis is relatively high $(90 \%$ at 5 years after diagnosis), occurrence of complications worsen this scenario to $30 \%$ at 3 years [210,211].

Liver cirrhosis was firstly associated with IGF-I in the late '80s, proposing this hormone as a good indicator for functional hepatocellular capability [212-214] with a marked decline from early cirrhosis stages (Child-Pugh A) [215]. Since then, the idea of liver cirrhosis as a condition of IGF-I deficiency during adult age has been yearly consolidated from a number of publications establishing the origin of this lack from a decrease in GH receptors seen in cirrhotic livers [216] and a progressive reduction of liver synthesis capability from decreased hepatocellular mass in advanced stages [209]. Furthermore, a marked decline of IGF-I has also been related to a higher probability of hepatocarcinoma [217] and poorer prognosis in patients requiring liver surgery [218]. As a result IGF-I levels are considered of prognostic value regarding survival in cirrhotic patients [215,218].

The availability of animal models for experimental liver cirrhosis (carbon tetrachloride, thioacetamide, bile duct ligation, D-galactosamine...) helped us to better elucidate the role of IGF-I in this pathology. In concrete terms, our group of work has reported that cirrhotic animals treated with rhIGF-I showed: increased food ingestion and efficiency with increased nitrogen uptake and balance (resulting in an increase in muscle weight) [219], normalization of intestinal amino acid and sugar absorption [220,221] (including in animals with advanced cirrhosis and ascites [222]), glucose metabolism [223], reduced portal pressure, endotoxemia and bacterial translocation [224], improved osteopenia both in compensated and ascetic cirrhosis $[225,226]$ and testicular morphology and function [227,228], recovered somatostatinergic tone [229] with improved liver function (increased albumin and coagulation factor levels) and decreased hepatic fibrosis [223]. We have also reported that the hepatic restoration was associated to antioxidant, antiapoptotic, antifibrogenic and mitochon drial-protective effects of IGF-I [230-234].

\section{Aging and age-related diseases}

Aging is a universal, intrinsic, irreversible, heterogeneous and multidimensional process of progressive involution characterized by a gradual loss of physiological functions that increases the probability of death. Although related, longevity is different from aging, since the first one is simply considered as the length of the life span independent of the biological aging process. Average lifespan has being (hopefully) continuously growing: from $\sim 27$ years in the Greco-Roman era, to $\sim 47$ years in 1900 , and $\sim 77$ years by the end of $20^{\text {th }}$ century [235]. However, it is very interesting that maximum lifespan (longevity) has not dramatically changed and seems to rest at about 120 years, despite the increase in the number of centenarians [236].

Circulating GH and IGF-I levels are maximal during peripubertal growth and early adulthood; however, they progressively decline with age [169]. This decline during human aging is sometimes referred to as somatopause, in analogy with the menopause and andropause. Reduced GH/IGF-I secretion in the elderly is believed to be responsible for or contribute to many symptoms of aging, including loss of muscle mass, increased adiposity, reduced bone mineral density, and decline in energy levels, along with alterations in psychological indicators of the quality of life [237].

There are diverse theories of aging [238] that basically point to few broad physiological processes important for longevity: genetic stability, telomere shortening, stress resistance and metabolic control. Interestingly, IGF-I is somehow related to all of them (Figure 3). Firstly, assuming that mitochondria are the main source of endogenous free radicals $[239,240]$, it has been previously reported that species with higher metabolic rates have shorter maximum lifespan due to superoxide anion radical accumulation that lead to cell damage, hastening aging [241]. At this point, we have previously shown that IGF-I is a main character in restoring mitochondrial dysfunction during aging by increasing mitochondrial membrane potential, reducing oxygen consumption, and increasing ATP synthesis what in turn minimize the ccytochrome release to the cytoplasm and subsequently promote neural survival by decreasing caspase-induced apoptosis $[55,56]$, in agreement with in vitro reported 


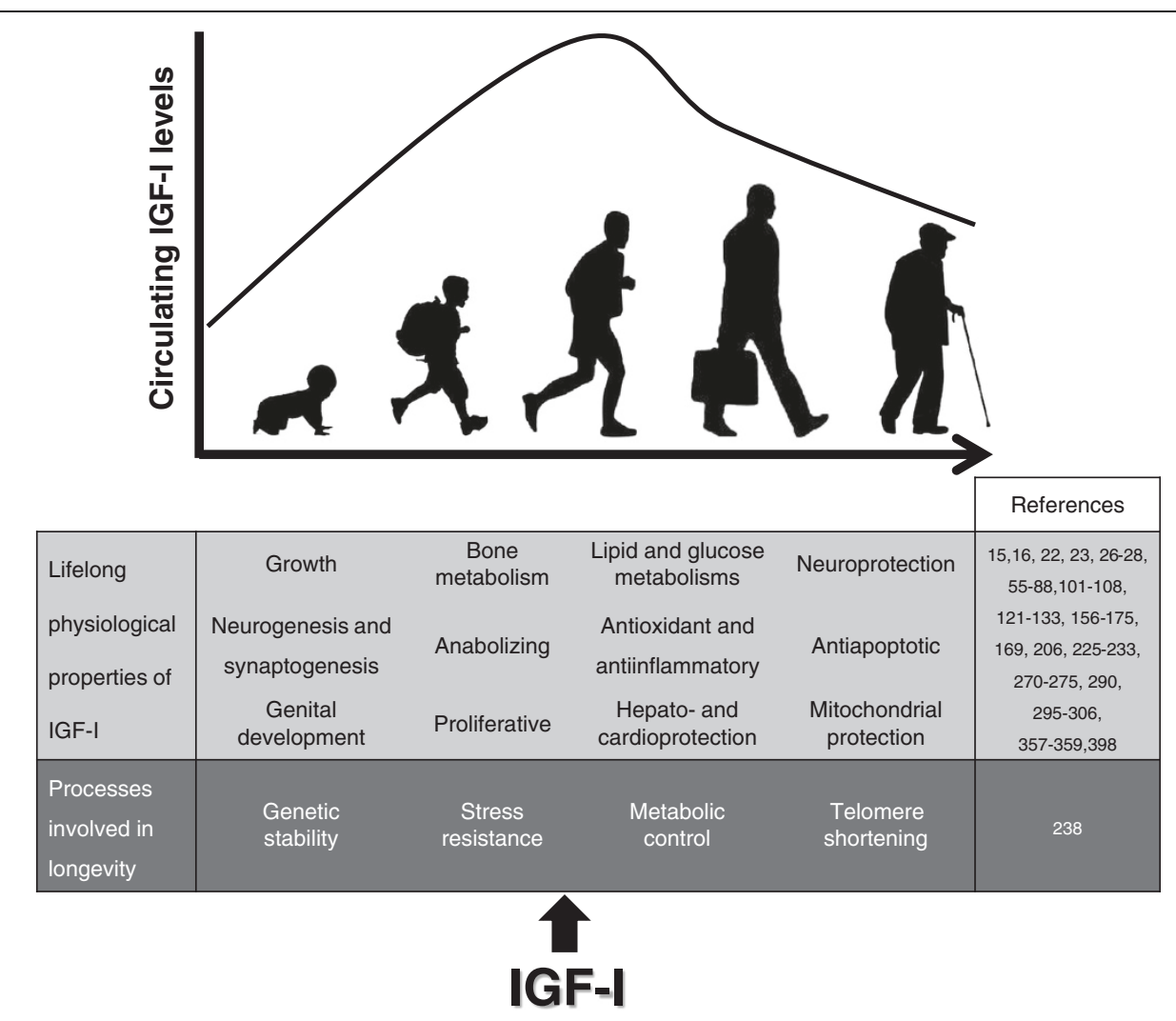

Figure 3 Lifelong beneficial properties of IGF-I. Evolution of IGF-I circulating levels and its pluripotent roles along different stages of human development and aging.

works from others [242-244]. Furthermore IGF-I's antioxidant capability in brain cortex and hippocampus was assessed as improving antioxidant enzymes activities (superoxide dismutase, catalase and glutathione peroxidase) and parameters of oxidative damage (MDA and PCC) $[55,56]$. Thus, by improving mitochondrial function and decreasing oxidative insults, IGF-I may be protecting DNA, proteins and lipids.

Secondly, IGF-I has been proposed as an index of healthy aging, due to the finding that it directly correlates with the leukocyte telomere length [245,246], a biomarker of human aging associated with increased risk of developing vascular diseases, metabolic disorders, and other age associated phenotypes [247,248].

And thirdly, another aspect where IGF-I may play a role in delaying aging symptoms is by controlling metabolism, together with insulin [249]. The best characterized intracellular substrates for the insulin and IGF-I receptors are the insulin receptor substrate proteins 1 to 4 [250]. Following tyrosine phosphorylation, each of these substrates associates with Src homology 2 (SH2) domains of intracellular molecules to generate downstream signals (cfr. Figure 4). The two most important $\mathrm{SH} 2$ molecules at this point are the adaptor molecule
Grb2 and the enzyme PI3K [251,252]. Grb2 links insulin action to the Ras-MAPK pathway, stimulating cell growth and differentiation. PI3K, on the other hand, is responsible for the insulin-like actions of the hormones by activating Akt/protein-kinase B (PKB) and proteinkinase $C$ (PKC), which subsequently leads to activation of p70 S6K and glycogen-synthase kinase 3 [252]. This, eventually results in stimulation of glycogen, lipid and protein synthesis, as well as in glucose transporter translocation to the plasma membrane with an increase in glucose transport [253]. Importantly, Akt/PKB also phos phorylates forkhead transcription factors of the FOXO subfamily, and this leads to their inactivation and retention in cytoplasm $[254,255]$ resulting in a reduced transcriptional activity [256]. As a final step, depending on the nature of the activation signal, FOXO can regulate apoptosis [257], cell cycle [258], differentiation [256], or the expression of genes involved in DNA repair [259] and oxidative stress resistance [260].

In addition, insulin sensitivity normally decreases during aging, and insulin resistance is a well established human risk factor for a variety of illnesses that affect morbidity and mortality among the elderly, including hypertension, atherosclerosis, obesity, diabetes and 


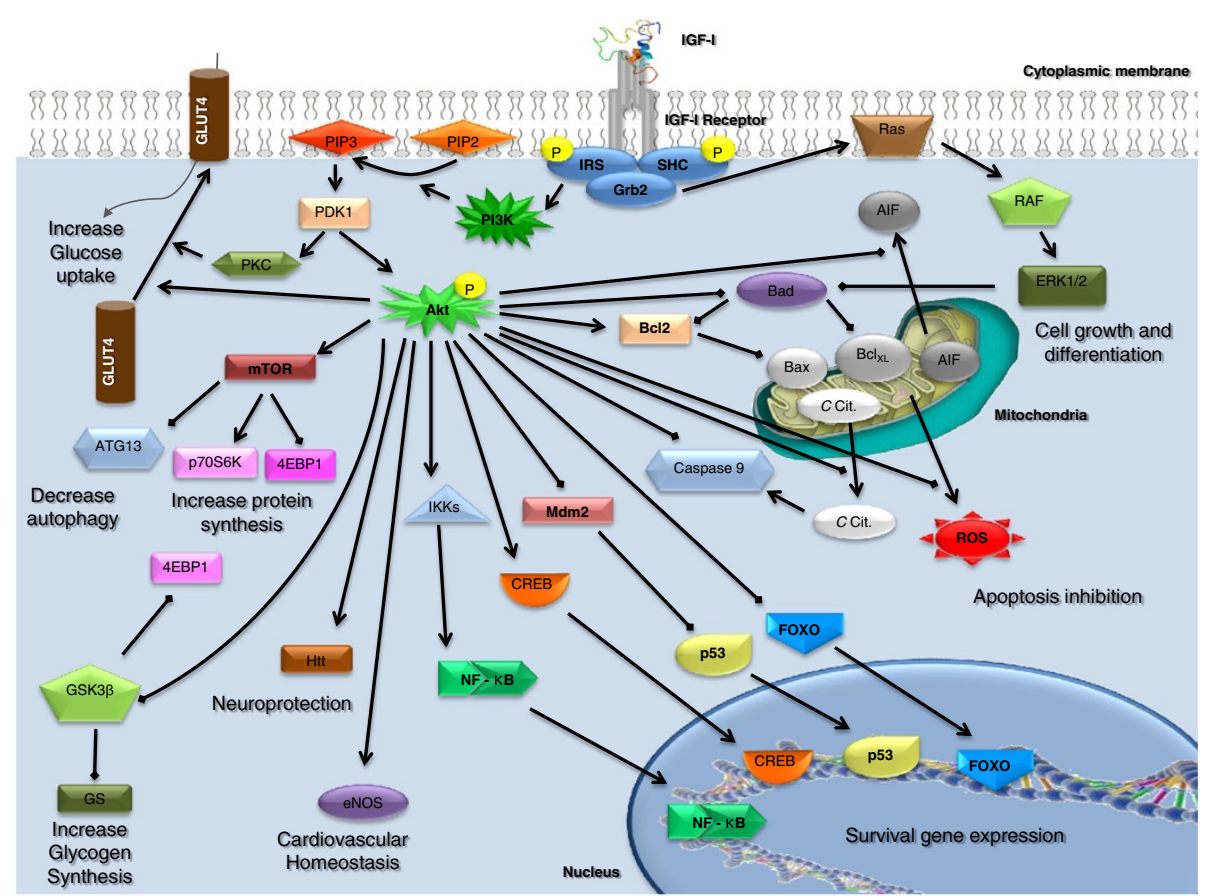

Figure 4 IGF-I receptor pathway. Activation of IGF-IR leads to a cascade of related molecules involved in previously described actions of IGF-I (survival, cell growth and differentiation, cytoprotection, glucose metabolism, etc).

neurodegenerative disorders [261-265]. In our group, we have demonstrated that low doses of IGF-I restored circulating IGF-I levels, which improves insulin resistance and lipid metabolism in aging rats [55], thus becoming a potential beneficial agent to prevent insulin resistancerelated pathologies.

As stated before, aging and longevity are different concepts. And this is also evident at the IGF-I function level. Despite all the beneficial effects of IGF-I described up to now and the following ones reporting its role in aging-related pathologies as musculoskeletal, neurodegenerative, cardiovascular diseases, IGF-I has been paradoxically negatively related to lifespan [266,267], probably due, at least in part, to its downstream molecule Akt and its interactions with FOXO, mTOR and SIRT-1, among others $[268,269]$. These outcomes demand much more work to elucidate the apparently contradictory actions of IGF-I on aging and longevity.

\section{Cardiovascular diseases (CVD)}

Cardiovascular diseases remain the biggest cause of deaths worldwide, though over the last two decades, cardiovascular mortality rates have declined in many highincome countries. At the same time cardiovascular deaths and disease evolution have increased at an astonishingly fast rate in low- and middle-income countries due to the increase in obesity, sedentary lifestyles and unhealthy habits [262].
Over the last years, low circulating IGF-I levels have been correlated with an increased risk for CVD in humans [270-274]. In cross-sectional studies, low circulating IGF-I levels were found to be associated with angiographically documented coronary artery disease [275] and may predict fatal ischemic heart disease [272], a significantly increased risk of ischemic stroke and congestive heart failure in elderly patients [276,277], as well as a worse prognosis of recovery after an acute myocardial infarction [278]. Additionally, it has been reported a positive correlation between circulating IGF-I levels and both coronary flow reserve [279] and successful cardiovascular aging in healthy centenarians [280].

Available data from transgenic mice with liver-derived IGF-I deficiency clarified that IGF-I deficiency per se can promote the development of an accelerated cardiovascular aging phenotype. Particularlly, contractility of cardiac myocytes is significantly impaired $[281,282]$ together with a deficient compensatory hypertrophic response, following experimental aortic constriction [281]. This animal model also exhibit a dysregulation of Nrf2-dependent antioxidant responses in the vasculature, which promotes the development of marked endothelial dysfunction and endothelial apoptosis in the presence of increased oxidative stress [281], mimicking the aging phenotype.

Consistently, a complementary strategy showed that in aged mice, where IGF-I levels are decreased, cardiac overexpression of IGF-I significantly improved cardiomyocyte contractile function [283], attenuating oxidative 
stress-mediated protein damage, normalizing $\mathrm{Ca}^{2+}$ homeostasis, reversing age-related alterations in the expression of pro-apoptotic proteins, and decreasing the apoptosis rate [284].

In a similar way, a role for locally produced IGF-I have also been documented. It was recently demonstrated that the paracrine IGF-I system confers vasoprotection and cardioprotection [285] and contributes to the maintenance of microvasculature structural and functional integrity. However, vascular paracrine IGF-I system cannot compensate for deficiency of circulating IGF-I [286].

Beneficial effects of the IGF-I/IGF-IR system in cardiac progenitor cells are also starting to be documented. Due to its great potential, this is a new field that deserves more recognition and study. The recent identification of a subpopulation of human cardiac stem cells expressing IGFIR and secreting autocrine IGF-I with a secondary therapeutic potential for myocardial regeneration [287,288], may be an important step toward this direction. Among others, actions of IGF-I on cardiac stem cells include antioxidant effects, upregulation of telomerase activity, a delay in replicative senescence [288], and migration and homing of cardiac stem cells facilitating neovascularization in damaged hearts [287].

Aging is associated with functional and phenotypic alterations in the microcirculation, including endothelial dysfunction, oxidative stress, chronic low-grade inflammation, and microvascular rarefaction (reduced number and combined length of small vessels in a given volume of tissue) [289]. Our current understanding is that both, circulating IGF-I levels and locally produced IGF-I, contribute to the maintenance of microcirculation functional and structural integrity, increasing NO bioavailability, decreasing reactive oxygen species (ROS) production, and exerting antiinflammatory, antiapoptotic, and proangiogenic effects. The mechanisms by which IGF-I reverses and/or prevents microvascular rarefaction and improves tissue blood supply are likely multifaceted, and may involve, among others: 1) Apoptosis, since IGF-I inhibits oxidative stress-induced apoptosis by preserving the functional integrity of the mitochondria [56,290]; 2) Angiogenesis, because IGF-I is known to exert significant pro-angiogenic effects, inducing proliferation of microvascular endothelial cells in culture through HIF- $1 \alpha$ and VEGF [291]; 3) Endothelial cell turnover, as it was reported that age-dependent impairment of endothelial progenitor cells is restored by the $\mathrm{GH}$ mediated increase in circulating IGF-I levels [292]; and 4) Oxidative stress and NO bioavailability, since age-related oxidative stress and downregulation of endothelial nitric oxide synthase (eNOS) impair the bioavailability of NO [293], which is likely to contribute to decreased microvascular density. Those facts were confirmed in animal models of IGF-I deficiency as they often exhibit increased ROS production and decreased NO bioavailability, mimicking the vascular aging phenotype [294]. Of interest, treatment of aged rats with IGF-I was shown to upregulate eNOS and improve bioavailability of NO [295], and in vitro experiments in cultured endothelial cells demonstrated that IGF-I treatment reduce ROS production and upregulate eNOS [294].

In the same way, it has been postulated that majority of these cardiovascular events related to low IGF-I levels may be due to a possible insulin resistance and accelerated atherosclerosis [296]. Also, the endothelial dysfunction and subintimal modified lipoprotein deposition are frequently consequence of oxidative stress [297] and inflammatory cells activity [298]. Antioxidant and antiinflammatory effects of IGF-I have been documented to reduce atherosclerotic burden, mainly both via cytokine response modulation (attenuating IL- 6 and TNF- $\alpha$ proinflammatory responses) [299] and/or eNOS activity regulation [295].

\section{Metabolic syndrome}

The metabolic syndrome was defined as a combination of clinical features that predispose to enhanced CVD risk, morbidity, and mortality [300]. In some populations, it is present in $\sim 50 \%$ of adults [301]. It is thought that an important underlying pathogenetic basis for the metabolic syndrome is insulin resistance and accompanying compensatory hyperinsulinemia [301].

Although without total consensus, six components have been proposed to constitute the metabolic syndrome [300]: Abdominal obesity (or increased waist circumference), atherogenic dyslipidemia (hypertriglyceridemia and low high-density lipoprotein cholesterol concentrations), raised blood pressure, insulin resistance with glucose intolerance, pro-inflammatory state (elevated C-reactive protein) and a pro-thrombotic state (with increased plasminogen activator inhibitor-1 and fibrinogen).

On the other hand, similarities between insulin and IGF-I (molecular homology, shared receptors...) point to the possibility of IGF-I participation in the phenotypic expression of this disorder [301]. The high insulin levels could probably cause a downregulation of IGF-I production by the liver and other tissues, as a compensatory homeostatic mechanism, induced most likely through a differential modulation of IGFBPs production. This might be responsible for the low IGF-I levels seen in association with states of insulin resistance, as the metabolic syndrome [301].

IGF-I's action on insulin suppression via somatostatine [1] has been tried in diabetes. In type 1 diabetes, where IGF-I and IGFBP-3 levels are decreased [302], substitutive rhIGF-I/IGFBP-3 therapy enhances protein [303] and glucose metabolism by controlling both endogenous glucose output and peripheral glucose uptake [304]. In 
type 2 diabetic patients, co-treatment with rhIGF-I can significantly reduce glucose levels and insulin requirement [305] while improving glucose tolerance, hyperinsulinemia, and hypertriglyceridemia [306]. Even in nondiabetic subjects, rhIGF-I enhances insulin sensitivity, suppresses lipolysis, clears postprandial lipemia, and increases oxidative and nonoxidative glucose metabolism $[223,307,308]$. The higher prevalence of insulin resistance and metabolic syndrome in older people compared with younger population may also be attributable, at least in part, to the decline of serum and tissue IGF-I concentrations with advancing age [55,307]. Reduced IGF-I levels are independently associated with glucose intolerance, diabetes, abdominal obesity $[309,310]$ and atherogenic dyslipidemia [311,312]. Overall, these data suggest an important and independent role for IGF-I in protecting against the development of CVD.

Indeed, many of the traditional CVD risk factors, including oxidized low-density lipoprotein [313], hyperlipidemia (hypercholesterolemia or mixed dyslipidemia) [314] insulin resistance [309,310,312], diabetes [315], obesity [309,311], elevated C-reactive protein [316], waist-to-hip ratio [309], reduced coronary flow reserve [279], smoking [317], sedentary life [318] and psychological distress [319], which act via effects on endothelial dysfunction, apoptosis and impaired endothelial-dependent vascular reactivity, have been associated with low serum IGF-I levels and reduced IGF-I and IGF-IR mRNA as well as protein expression in vascular smooth muscle cells (VSMC) [313]. Initially described as a pro-atherogenic molecule due to its proliferative role in VSMC, it was further demonstrated that the effect of IGF-I on VSMC was to compensate for local apoptosis, and that, overall, IGF-I is not pro-atherogenic in native arteries but antiatherogenic [320], mainly through enhanced nitric oxide production [308]. In addition, IGF-I induces vasodilatation [279,321,322], thereby influencing the regulation of vascular tone and arterial blood pressure and preserving coronary flow reserve [279,321], platelet function, and glucose uptake [323].

Finally, it was recently suggested that IGF-I has significant characteristics to be a good marker for the insulin resistance syndrome and risk of cardiovascular disease, since logistic regression analysis showed that each unit increase in log-transformed IGF-I concentrations was associated with a $90.5 \%$ reduction in the risk of metabolic syndrome [274].

\section{Neurodegenerative diseases}

Neurodegenerative diseases are a heterogeneous group of disorders from virtually unknown etiology, which eventually lead to neuronal degeneration and dysfunction. As described before, since GH/IGF-I axis is involved in many aspects of brain development, growth and function, their progressive decrease during aging could be involved in a variety of human cerebrovascular diseases, comprising Alzheimer's disease (AD), vascular dementia (VD), amyotrophic lateral sclerosis (ALS) and stroke.

Alzheimer's disease and vascular dementia are the most common forms of dementia in elderly [324]. A decrease in IGF-I levels in AD and VD has been widely documented and it may be involved in the development of neurofibrillary tangles, abnormal amyloid $\beta$ metabolism and aberrant Tau phosphorylation, cognitive loss, neural inflammation, oxidative stress or mitochondrial dysfunction, among others [68,325].

Specifically, IGF-I has been proposed as a physiological regulator of brain amyloid levels [68] by the entrance/production through the brain barrier of different proteins involved in $A \beta$ transport, which eventually enhances its brain efflux $[68,326]$. In fact, blockade of systemic IGF-I action at the choroid plexus was sufficient to induce brain amyloidosis [326].

Another well recognised neuropathological finding in $\mathrm{AD}$ is the accumulation of abnormally hyperphosphorylated Tau in degenerating neurons [325]. Based on the known role of insulin/IGF-I as inhibitors of Tau phosphorylation by inhibiting a major Tau kinase, such as glycogen synthase kinase- $\beta$, numerous observations demonstrated that IGF-I controls the levels of hyperphosphorylated Tau in brain [326,327]. Two other pathological processes underlying neuronal decline in $\mathrm{AD}$ are gaining attention: oxidative stress and inflammation $[328,329]$. Again, antiinflammatory and antioxidant effects of IGF-I, together with its antiapoptotic capability, endorse IGF-I as a suitable candidate for AD treatment. Thus, although more work in animal models are required, the available evidence strongly indicates that IGF-I therapy in Alzheimer's dementia may address etiopathogenic processes and could be a potential candidate for clinical trials.

On the other hand, amyotrophic lateral sclerosis is the most common motor neuron disorder in human adults. In this pathology, IGF-I levels diverge between studies, from increased to decreased IGF-I concentrations [330-332], probably due to differences in samples origin (serum/cerebrospinal fluid vs spinal cord/musculoskeletal) and could be explained as a physiological defensive mechanism promoted in response to the neural degeneration and/or muscle atrophy. Beneficial effects of IGF-I treatment in ALS have been demonstrated both in vivo and in vitro, from which IGF-I has been postulated as an important factor for the maintenance and survival of motor neurons in the spinal cord by activating clue pathways as PI3K/Akt and p44/42 MAPK [333] and ameliorating the superoxide effect [334]. Based on the strength of the pre-clinical evidence, two randomized double-blind placebo-controlled phase III trials examining the efficacy 
of subcutaneous rhIGF-I in the treatment of ALS have been completed [335,336]; however, the results of these two trials conflict, concluding, that more complex studies to set the potential role of IGF-I in ALS disease are required.

Along with this, cerebrovascular accident (CVA) is currently the second leading cause of death in the Western world, ranking after heart disease and before cancer [337], and experts predict that it is likely to be soon the most common cause of death worldwide [338]. Studies on patients with ischemic stroke suggest that high circulating IGF-I levels are associated with neurological recovery and a better functional outcome [339], probably due to its neuroprotective and pro-angiogenic effects. In fact, increased cerebrovacular mortality in patients with hypopituitarism was documented last century [340]. Importantly, as the nervous system ages, there is also a rarefaction of the microvasculature in different regions of the brain, as well as alterations in the structure of the remaining vessels, which have been causally linked to cognitive dysfunction in older humans [341,342]. This age-related microvascular rarefaction contributes to a decline in regional cerebral blood flow that reduces metabolic support for neural signaling, especially when neuronal activity is high. Of great interest, infusion of IGF-I was shown to elicit a significant $(\sim 40 \%)$ increase in cerebromicrovascular density in the adult mouse brain [343], via stimulation of HIF- $1 \alpha$ and its downstream effector, VEGF.

Menupause and insulin resistance have independently been involved in the incidence of neurodegenerative diseases [344]. Several studies have pointed to PI3K activation as a pivotal event for estradiol effects, a common pathway for IGF-I and insulin [344]. Therefore, it seems possible that estrogen receptor alpha may interact with IGF-I/insulin signaling pathways, to promote neuroprotective effects in brain. Current investigations are also evidencing the role exerted by other key signalling molecules, such as glycogen synthase kinase 3 and beta-catenin, in the cross-talk of estrogen receptors and IGF-I receptors in neural cells [345].

Cognition and memory also decline with age, and they have been correlated to low IGF-I levels as well [346-349], through a proposed mechanism that may include its role in angiogenesis and neurogenesis in the hippocampus. Interestingly, the phosphodiesterase inhibitor Cilostazol (used in peripheral vascular disease treatment) is able to improve cognitive function in mice by increasing the hippocampal production of IGF-I through stimulation of sensory neurons [350].

\section{Musculoskeletal disorders}

Aging is associated with a decline in skeletal muscle mass, sometimes referred to as "sarcopenia of old age". There are several underlying mechanisms that have been implicated in this age-related muscle wasting: decreased protein synthesis, reduced enzymatic activity (especially in glycolytic and glycogenolytic pathways), depletion in energy reserves, increased oxidative damage, and changes in ion content [351], among others. GH and IGF-I have a significant anabolic effect on skeletal muscle and so their decline with aging likely contributes to the decline in muscle mass. For example, they can promote mitosis, protein synthesis, satellite cell proliferation and nerve sprouting, while preventing apoptosis [352,353]. However, in general, tissue responsiveness to IGF-I is altered with aging. Thus, it was reported that median IGF-I and IGFBP-5 mRNA levels in resting young muscle are more than twice higher than those in elderly muscle [354], and aging is associated with decreases in IGF-IR content and IGF-IR phosphorylation in muscle [355].

Skeletal health may also be compromised in vertebrates with reduced GH/IGF-I signaling. Like muscle, normal aging is associated with both quantitative and qualitative changes in bone, including alterations in trabecular architecture, mineralization, protein content and the accumulations of microfractures [356]. IGF-I, which mediates most of the effects of $\mathrm{GH}$ on skeletal metabolism, promotes chondrogenesis and increases bone formation by regulating the functions of the differentiated osteoblasts $[357,358]$. Furthermore, in fibroblasts, DNA synthesis and cell proliferation in response to IGF-I decrease with elderly [359]. Bone responsiveness to IGF-I also decreases with aging, requiring higher doses to reach the same anabolic effect [360]. These studies suggest that low circulating IGF-I bioactivity and/or abnormalities of IGF-I signaling in elderly subjects, may play an important role in age-related sarcopenia and osteopenia, where the substitutive IGF-I treatment may be a suitable therapeutic strategy, although this apparent IGF-I resistance may dampen this aim.

\section{Other IGF-I deficiency conditions Renal diseases}

As previously stated, the IGF system is involved in normal kidney development, and age-related dysregulation of this system may play a role in kidney and vascular diseases, including hypertension [138]. In addition, under renal dysfunction conditions there are profound changes in renal responses to GH/IGF-I system as well as in the circulating levels of these hormones, despite the limited role of the kidney for removing IGF-I from the circulation (since negligible amounts of the IGFBP-3/ALS/ IGF-I ternary complex crosses the glomerular barrier in healthy individuals) [361].

In mice with global inactivation of the IGF-I gene, the proportionally reduced kidney size associates with reduced glomerular size and decreased numbers of nephrons 
[362]. In addition, IGF-I has rapid effects on renal hemodynamics, including an increased renal blood flow and glomerular filtration rate $[138,141,142]$. Furthermore, both IGF-I and the IGF-IR are expressed in the developing glomerulus and patterns of expression are disrupted in animal models and in human examples of renal disease [140]. Indeed, it has been demonstrated a role of IGF-I signaling for maintaining glomerular integrity, restoring podocyte abnormalities, inhibiting podocyte apoptosis, and alterations in the glomerular basement membrane and the adjacent endothelial cell layer [140,363].

In humans, IGF-I also increases renal blood flow and GFR by $\sim 25 \%$ and causes volume expansion and sodium retention by a direct action on the renal tubules, with stimulation of rennin release and suppression of atrial natriuretic peptide secretion [364]. IGF-I administered to GH deficient rats (or to patients with $\mathrm{GH}$ receptor defects) normalizes the low GFR as does GH replacement in GH deficiency. Curiously, the effects of GH on kidney function are similar to those observed with IGF-I, except that the functional response to $\mathrm{GH}$ is delayed several days, correlating with the secondary increase in serum IGF-I levels, and thus indicating that the GH effects are mediated by IGF-I. However, it is noteworthy that $\mathrm{GH}$ receptors are present in the proximal tubule, a site where IGF-I mRNA is not normally expressed, suggesting that $\mathrm{GH}$ also may have direct actions on tubular function [364].

In another hand, while most reports appear to implicate IGF-I as a potential mediator of pathological changes in the diabetic kidney [364,365], IGF-I is also protective against oxidative stress and apoptosis induced by high levels of glucose in cultured mesangial cells. This protection appears to be mediated by Akt/PKB and MAPK signalling pathways [366], and it has been suggested that stimulation of this survival pathways may be turned to therapeutic advantage for protection against cell death and progression of nephropathy.

\section{Catabolic states}

Clinical investigators have shown that IGF-I levels are often significantly altered in catabolic states, including the acute postoperative period [367], burn patients [368] and chronic catabolic illnesses, such as cystic fibrosis [369] and HIV with wasting [370]. These conditions result in low IGF-I concentrations, and changes in IGF-I positively correlate with changes in lean body mass $[369,370]$, as well as reversal of acute catabolic states is associated with an increase in IGF-I levels [371,372]. In clinical use, children with extensive thermal burns who were treated with IGF-I in combination with IGFBP-3, presented a reduction in serum levels of IL-1 $\beta$, TNF- $\alpha$, C-reactive protein, $\alpha 1$-acid glycoprotein, and complement C-3 [299]. In contrast, the serum levels of retinolbinding proteins, prealbumin, and transferrin were increased by the infusion. From these results, authors concluded that attenuating the pro-inflammatory acute phase with IGF-I/IGFBP-3 may prevent multiple organ failure and improve clinical outcomes after thermal injury without any detectable adverse side effects.

Also, when IGF-I was used to monitor total parenteral nutrition therapy in catabolic patients, the changes correlate with improvements in protein metabolism [373]. Consistently, a close correlation between IGF-I and protein synthesis in patients with burns was reported [368]. Similarly, extremely low IGF-I levels observed in severe malnutrition improved with caloric repletion [374].

\section{Current therapeutic options and limitations}

The pluripotential roles of IGF-I may explain the interest and wide availability of IGF-I assays from different laboratories. However, standard methods of IGF-I measurement are not well characterized yet. Recombinant human IGF-I was first available for experimental therapy in the late 1980s, what allowed the development of longterm studies in children with severe primary IGF-I deficiency (defined as a height SDS and IGF-I SDS less than or equal to -3 and normal or elevated $\mathrm{GH}$ levels) [375]. These studies followed the children for up to 12 years and reported a significant dose-dependent increase in mean first-year height velocity over baseline $(\sim 3.0 \mathrm{~cm} /$ year at baseline, $\sim 8.5 \mathrm{~cm} /$ year at first year, $\mathrm{p}<0.001)$ [376-380]. Mean height velocity decreased during the subsequent years of treatment, but remained higher than the pretreatment height velocity for up to 8 years [376]. A complementary aspect of the rhIGF-I treatment in these patients was an increase in testosterone levels, testicular size and stretched penile length, which indicates a direct effect of IGF-I on sex hormones and organs in male patients [381].

These studies supported the 2005 US Food and Drug Administration (FDA) approval of rhIGF-I, being commercially available in 2005 for treatment of patients with severe primary IGF-I deficiency due to genetic GH resistance from mutations in the $\mathrm{GH}$ receptor, defects in the $\mathrm{GH}$ receptor signaling pathway (including STAT5b gene mutations), mutations in the IGF-I gene, or in rare patients with $\mathrm{GH}$ gene deletions in whom inactivating antibodies develop to exogenous rhGH [382-384], but not for other conditions of (secondary) IGF-I deficiency such as malnutrition, hypothyroidism and chronic illnesses [383]:

- Active or suspected neoplasia.

- Allergy to rhIGF-I (mecasermin, Increlex ${ }^{\circledR}$ ) or any of its ingredients.

- Chronic illness (i.e. diabetes, cystic fibrosis, etc.).

- Growth failure associated with other identifiable causes (i.e. Prader-Willi syndrome, Russell-Silver 
syndrome, Turner syndrome, Noonan syndrome or chromosomal abnormalities).

- Patients with closed epiphyses (for promoting growth treatments).

By the same time, FDA also approved the use of the combination of IGF-I and IGFBP-3. Theoretically, it might be a better choice as a more physiological strategy (which would require lower doses). However, the results were not as promising as expected and legal issues led to its discontinuation. Interestingly, a recent work developed in two brothers with insulin-like growth factor deficiency, where one was treated with IGF-I plus IGFBP-3 and the other with just IGF-I, showed that both modalities improved determinants of hepatic insulin sensitivity, body composition and linear growth rate; however, IGF-I alone seemed to be more efficient [385].

A complete review by Laron in 2008 [386] summarizes the experience by several groups worldwide. The main conclusions were: 1) The one or two injections regimen result in the same growth velocity; 2) The growth speed obtained with IGF-I administration is smaller than that observed with hGH in children with congenital isolated GH deficiency; 3) Overdosage of IGF-I causes a series of adverse effects which can be avoided by carefully monitoring the serum IGF-I and GH levels. The optimal dosing guidelines are still on debate. Firstly stated on the basis of IGF-I tolerance, two more recent studies presented at the International Congress of Endocrinology (2008) showed the safety and efficacy of both twice-daily $(80-120 \mu \mathrm{g} / \mathrm{Kg})$ or once-daily $(240 \mu \mathrm{g} / \mathrm{Kg})$ rhIGF-I treatment for primary IGF-I deficiency $[387,388]$. Interestingly, it was also reported a certain degree of heterogeneity in the serum IGF-I responses, probably influenced on the IGFBP-3 levels [389].

Another disturbing aspects are the difficulties found when collecting, storing and monitoring IGF-I serum samples [389,390]. In contrast to $\mathrm{GH}$, circulating levels of IGF-I remain relatively stable during daytime with minimum oscillations, being unaffected by meal intake [391,392]. However, IGFBP-3 levels showed acute changes with meal intake [391-393], what has direct consequences on IGF-I bioavailability, and it was reported a nocturnal decline of IGF-I levels from midnight to 4 am [393], probably due to shifts in plasma volume. Despite this, the lack of any major diurnal variation in circulating IGF-I levels, combined with the long half-life of ternary complex constituting IGF-I [393] has led to the concept that a single measurement of IGF-I is representative for an individual IGF-I level. On the other hand, the serum half-life of rhIGF-I is less than 24 hours, what suggests that serum IGF-I monitoring may be worth for detecting a single missing dose on the day, but it is not useful for identifying long term treatment noncompliance [394]. Furthermore, there is no clear indication to date that routine serum IGF-I monitoring is informative or useful for children taking rhIGF-I treatment, as it has not been linked to the occurrence of adverse events or efficacy outcomes [387-389].

Safety is the paramount aim when developing new drugs. In this case, as previously happened with recombinant technologies for GH and insulin, IGF-I is a natural peptide already produced in humans, what facilitates the elucidation of possible secondary effects due to rhIGF-I therapy. However, a number of clinical trials monitoring long-term rhIGF-I treatment have reported different adverse events [372,377,387-389,395-398], although they were transient, well tolerated and easy managed without treatment discontinuation (Table 1). In brief, it has been reported episodes of tachycardia (self-resolved and probably due to the inotropic effect of rhIGF-I), transient increase of intracranial pressure with headache and vomiting (consistent with the safety profile of rhGH treatment), lipohypertrophy at injection site, tonsillar/adenoidal hypertrophy, facial edema, arthralgia, myalgia, asthenia, orthostatic hypotension and hypoglycemia. This decrease in blood sugar could be a consequence of the insulin like action of IGF-I per se, and the binding of IGF-I to the insulin receptor. However, a placebo controlled study by GuevaraAguirre et al. in 1995 reported no statistically significant difference in the frequency of hypoglycemia in those who received IGF-I vs. placebo for 6 months (86\% in IGF-I group vs. $67 \%$ in the placebo group) [379]. Interestingly, as previously stated by Laron [386], doses lower than $60 \mu \mathrm{g} / \mathrm{Kg} /$ day did not show these described adverse effects, both in human clinical trials $[398,399]$ and in animal experimental models [55,56,219-221,223].

Table 1 Reported adverse effect during IGF-I treatment

\begin{tabular}{lcc}
\hline Adverse effect & $\begin{array}{c}\text { IGF-I doses }(\boldsymbol{\mu g} / \mathbf{K g} / \\
\mathbf{d a y})\end{array}$ & References \\
\hline Tachycardia & $150-200$ & {$[397]$} \\
& $120-180$ & {$[398]$} \\
Hypoglycemia & $60-120$ & {$[377,380]$} \\
& $80-120$ & {$[378,387]$} \\
Intracrenial pressure increment & $80-120$ & {$[378,387]$} \\
Lipohypertrophy & $60-120$ & {$[377,387]$} \\
Tonsillar/adenoidal hypertrophy & $60-120$ & {$[377,387]$} \\
Headache and vomiting & $80-120$ & {$[387]$} \\
Facial edema & $120-180$ & {$[398]$} \\
& 120 & {$[373]$} \\
Asthenia, orthostatic & 120 & {$[373]$} \\
hypotension & & {$[373]$} \\
Arthralgia/myalgia & 120 &
\end{tabular}

Subcutaneously, daily, for at least 1 year. 
Another outcome from the rhIGF-I treatment in Laron syndrome is the significant increase in body adipose tissue (to double or triple the normal values) concomitantly with the increase in growth [400] although, due to the underdevelopment of the muscular and skeletal systems, body mass index did not accurately reflect the degree of obesity. From these data, authors concluded that IGF-I, similar to insulin, exerts an adipogenic effect. However, another study in insulin resistance, reported a reduction in both intramyocellular lipids and intrahepatic fat in a patient treated with rhIGF-I/IGFBP-3 (together with a post-treatment normalization of \% HbA1C value) [401]. These data, although very preliminary, may indicate different mechanistic pathways by which IGF-I controls lipid metabolism.

Consistently, despite these known effects, we still must be alert due to the reported potential role of IGF-I in neoplasias development (a recommended review is available at ref. [402]). Fortunately, a recent study shed some light on this topic by reporting the malignancies occurrence in patients with congenital IGF-I deficiency and insensitivity to GH. They found that this condition seemed to be protective against future cancer development, but more interesting, even when treated with IGF-I [403]. Furthermore, no current data in the literature suggest the malignant transformation of a normal cell in association with IGF-I administration, what may reassure possible concerns about its long-term safety and use in replacement therapies.

Nowadays, rhIGF-I therapy is also being tested or proposed in other pathological conditions as chronic liver disease, insulin resistances/hyperinsulinemia, diabetes, neurological disorders (Alzheimer's disease and amyotrophic lateral sclerosis) and stroke, cysticfibrosis, wound healing, AIDS muscle wasting and HIVassociated adipose redistribution syndrome, burns, osteoporosis, Crohn's disease, Werner syndrome, Xlinked severe combined immunodeficiency, myotonic muscular dystrophy, hearing loss prevention, spinal cord injury, cardiovascular protection, anorexia nervosa, fetal growth restriction and prevention of retinopathy of prematurity [182,303-306,384,399,401,404-423], although some of the treatment's contraindications may limit its potential applicability (Table 2).

Nonetheless, in spite of the great amount of data obtained from these studies, there is still a necessity for further studies to either elucidate the right doses to achieve the expected results, clarify the rhIGF-I therapy effectiveness or even exclude any potential adverse event. For example, the effect of rhIGF-I in chronic liver injury $(20 \mu \mathrm{g} / \mathrm{Kg} /$ day with dose escalation up to $50-$ $100 \mu \mathrm{g} / \mathrm{Kg} /$ day for 4 months) was mainly reduced to an increase in albumin levels [399], probably due to the low number of subjects and treatment guidelines, which could not achieve normal IGF-I values, as was also reported in a recent study [387] where doses by $40 \mu \mathrm{g} / \mathrm{Kg} /$ day did were not able to normalize serum IGF-I.

In our experience, the most important goal is to prove the presence of IGF-I deficiency. However, in some cases like compensated liver cirrhosis, IGF-I circulating levels are normal, but if low doses of this hormone are administrated, many beneficial effects are induced [219-221,223,225,228,232]. This finding suggests that the bioavailability of IGF-I is reduced from early stages of liver disease. However, without hepatopathy, IGF-I levels and bioavailability are not diminished. Thus, IGF-I treatment failed to induce the desired effects, like was reported in a model of testicular dysfunction secondary to epinephrine intra-scrotal

Table 2 Current proposed IGF-I treatments

\begin{tabular}{|c|c|}
\hline Pathological condition & References \\
\hline Laron Syndrome & $\begin{array}{l}{[33-35,200-208} \\
381-389,397]\end{array}$ \\
\hline Liver cirrhosis & {$[219-234,399]$} \\
\hline Aging & {$[55,56,169,245-248,384]$} \\
\hline IUGR & {$[37-41,182-197]$} \\
\hline Neurological disorders & {$[335,336,405-407]$} \\
\hline Stroke & {$[337,413]$} \\
\hline Spinal cord injury & {$[421]$} \\
\hline Cardiovascular protection & {$[270-277,310,415]$} \\
\hline Diabetes & [302-306] \\
\hline Insulin resistances/hyperinsulinism & {$[55,404,409,423]$} \\
\hline Metabolic syndrome & {$[301,316]$} \\
\hline Osteoporosis & {$[416,417]$} \\
\hline Cystic fibrosis & {$[408]$} \\
\hline Wound healing & {$[410]$} \\
\hline Myotonic dystrophy & {$[419]$} \\
\hline AIDS muscle wasting & {$[411]$} \\
\hline HIV-associated adipose redistribution syndrome & {$[411]$} \\
\hline Burns & {$[299]$} \\
\hline Crohn's disease & {$[412]$} \\
\hline Werner syndrome & {$[417]$} \\
\hline X-linked severe combined immunodeficiency & {$[418]$} \\
\hline Hearing loss prevention & {$[414]$} \\
\hline Anorexia nervosa & {$[420]$} \\
\hline Retinopathy of prematurity & {$[422]$} \\
\hline
\end{tabular}

rhIGF-I replacement therapy may be recommended only to restore IGF-I deficiency conditions. In consequence, despite the number of proposed pathological conditions that may benefit from rhIGF-I treatment, up to date, only those in the white have been well characterized. Conditions in clear grey are supported by a wide body of evidence which render these circunstances prone to be classified as the first group. Dark grey are conditions that may need more research in order to adequately propose the IGF-I treatment as a proper strategy. 
injections (but without liver cirrhosis or any other condition of IGF-I deficiency) [424].

At this point, it is also crucial to state that testicular dysfunction was only restored when it was associated to IGF-I deficiency conditions, since IGF-I treatment of rats with testicular damage secondary to epinephrine intra-scrotal injections (but without liver cirrhosis or any other condition of IGF-I deficiency) was not able to adequately recover their morphology and function.

On the other side, therapeutic use of rhIGF-I has been debated in ALS, since a Cochrane systematic evidence review found that the available randomized placebo controlled trials $[335,336]$ did not permit a definitive assessment of its clinical efficacy [407], with just a small significant benefit in favor of recombinant IGF-I, which clinical relevance is unclear. The authors concluded that more research is needed, noting that one trial is in progress, and they recommended that future trials may include survival rates as another outcome measure.

And thirdly, although Rosenbloom [384] stated that the rhIGF-I insulin-sensitizing effect may be beneficial for diabetic patients to reduce hemoglobin $\mathrm{A} 1 \mathrm{C}$ levels, there are no current ongoing clinical trials because of concern about risk of retinopathy and other complications [425], thus limiting the theoretically wide spectrum of potential IGF-I treatment indications.

\section{Conclusions}

Briefly, IGF-I deficiency states -as it is the case with every other hormone- produce effects that culminate in recognizable syndromes with significant clinical consequences. Until now, the best known conditions of IGF-I deficiency are: Laron Syndrome, in children; advanced liver cirrhosis, in adults; and aging including cardiovascular and neurological diseases associated to aging. More recently, intrauterine growth restriction seems to appear as another state of IGF-I deficiency. In these four conditions, the replacement therapy can logically induce beneficial actions. Apart from these, many other diseases have been recently proposed to be either consequence or cause of both a systemic or partial IGF-I deficiency. However, more in-depth studies are needed to properly characterize these potential new conditions of IGF-I deficiency and their future clinical perspectives.

On the other hand, the multiple physiological properties of IGF-I may generate excessive prospects if basic concepts about this topic are not adequately considered:

1. IGF-I is a closed regulated hormone. Its therapeutic applications should, in principle, be limited to restore physiological levels, but not over its normal range, as it is the usual practice in endocrinology diseases (hypothyroidism, diabetes, etc.).
2. Exogenous administration of IGF-I in conditions without IGF-I deficiency, usually responds to an attempt to exploit its anti-inflammatory, hematopoietic, antioxidant, metabolic or anabolic properties. However, despite the limited results of these strategies, it may entail obvious risks. In the best of cases, these strategies would require prudence and short periods of treatment, as in the corticotherapy.

3. Low doses of IGF-I seem to be able to restore circulating levels of this hormone promoting beneficial effects without secondary effects (including hypoglycemia). Secondary adverse effects from IGF-I therapy were reported after administration of doses higher than $60-80 \mu \mathrm{g} / \mathrm{Kg} /$ day.

4. The axis GH/IGF-I is claiming a particular physiological understanding. Usually IGF-I deficiency is associated to "GH resistance" or "GH insensibility" states. IGF-I replacement therapy induced a restoration of the altered GH/IGF-I axis by reducing circulating $\mathrm{GH}$ levels and improving somatostatinergic tone. Thus, IGF-I therapy would need to be considered as a different strategy from $\mathrm{GH}$ treatment, avoiding past inadequate procedures when both GH/IGF-I therapies were considered equivalent.

5. Finally, a concern about the potential relationship between IGF-I and cancer is an awkward issue that may require a deeper approach. For instance, a question may arise: are the higher circulating IGF-I levels a marker or a causal factor? In our experience, IGF-I at low doses is a cytoprotective factor that, exerting effective mitochondrial protection, antiinflammatory and antioxidant activities, could prevent oncogenesis and cancer development by acting in the earliest stages of these pathogenic mechanisms. In addition, despite permanent reservations relating cancer and IGF-I, no current data suggest an IGF-I related malignant transformation from a normal cell.

In conclusion, on the basis of the available evidence, and despite the current limitations in this matter, it seems reasonable that IGF-I therapies may be designed only to restore its physiological levels as a replacement treatment, but never elevating IGF-I levels above its upper normal range.

\section{Abbreviations}

ALS: Acid-labile subunit; AB: Amyloid $\beta$; BBB: Blood-brain barrier; CVA: Cerebrovascular accident; EGF: Epidermal growth factor; CNS: Central nervous system; CVD: Cardiovascular diseases; EAE: Experimental autoimmune encephalomyelitis; FDA: Food and drug administration; FSH: Follicle-stimulating hormone; GFR: Glomerular filtration rate; GH: Growth hormone; GHBP: Growth hormone binding protein; GHI: Growth Hormone Insensitivity; HGF: Hepatocyte growth factor; HIF: Hypoxia inducible factor; 
HPA: Hypothalamo-pituitary-adrenal; IGF: Insulin-like growth factor; IGFIR: Receptor de IGF-I; IGFBP: Insulin-like growth factor binding protein: IL: Interleukin; IUGR: Intrauterine growth restriction; LH: Luteinizing hormone; LS: Laron syndrome; MAPK: Mitogen-activated protein kinase; MDA: Malondialdehyde; NO: Nitric oxide; NSILA: Non-suppressible insulin-like activity; NSC: Neural stem cells; PCC: Protein carbonyl content; PI3K: Phosphatidylinositol-3-kinase; Rh: Recombinant human; ROS: Reactive oxygen species; SDS: Standard deviation score; SH2: Src homology 2; TNF-a: Tumor necrosis factor-alpha; VEGF: Vascular endothelial growth factor; VSMC: Vascular smooth muscle cells.

\section{Competing interests}

Authors have nothing to disclose.

\section{Authors' contributions}

JEP participated in compiling data and elaborating the manuscript. ICC critically revised the intellectual content of the review, and gave the final approval. All authors read and approved the final manuscript.

\section{Acknowledgements}

The authors would like to thank every researcher that contributed to the better understanding of the IGF-I role both in physiological and pathological conditions. We also appreciate Mr. Gonzalo Cañas Guevara imaging processing, and Mrs. Amalia Calderón and Mrs. Susana Arahuetes for their generous and expert secretarial and technical assistance. Special thanks to Kabi Pharmacia (Drs. Anna Sköttner and Jan Holmberg) and Chiron Company (Dr. Bruce Scharschmidt) for kindly providing the recombinant human insulin-like growth factor used in our studies. This work was supported by the Spanish "I+D Program" SAF 2009-08319.

Received: 11 July 2012 Accepted: 7 November 2012 Published: 14 November 2012

\section{References}

1. Le Roith D: Seminars in medicine of the beth israel deaconess medical center. Insulin-like growth factors. N Engl J Med 1997, 336(9):633-640.

2. Salmon WD Jr, Daughaday WH: A hormonally controlled serum factor which stimulates sulfate incorporation by cartilage in vitro. J Lab Clin Med 1957, 49(6):825-836.

3. Froesch ER, Buergi $H$, Ramseier EB, Bally P, Labhart A: Antibodysuppressible and nonsuppressible insulin-like activities in human serum and their physiologic significance. An insulin assay with adipose tissue of increased precision and specificity. J Clin Invest 1963, 42:1816-1834.

4. Pierson RW Jr, Temin HM: The partial purification from calf serum of a fraction with multiplication-stimulating activity for chicken fibroblasts in cell culture and with non-suppressible insulin-like activity. J Cell Physiol 1972, 79(3):319-330

5. Daughaday WH, Hall K, Raben MS, Salmon WD Jr, van den Brande JL, van Wyk JJ: Somatomedin: proposed designation for sulphation factor. Nature 1972, 235(5333):107.

6. Rinderknecht $E$, Humbel RE: The amino acid sequence of human insulinlike growth factor I and its structural homology with proinsulin. J Biol Chem 1978, 253(8):2769-2776.

7. Rinderknecht $E$, Humbel RE: Primary structure of human insulin-like growth factor II. FEBS Lett 1978, 89(2):283-286.

8. Klapper DG, Svoboda ME, Van Wyk JJ: Sequence analysis of somatomedinC: confirmation of identity with insulin-like growth factor I. Endocrinology 1983, 112(6):2215-2217.

9. Zapf J, Schoenle E, Froesch ER: Insulin-like growth factors I and II: some biological actions and receptor binding characteristics of two purified constituents of nonsuppressible insulin-like activity of human serum. European journal of biochemistry / FEBS 1978, 87(2):285-296.

10. Froesch ER, Zapf J, Audhya TK, Ben-Porath E, Segen BJ, Gibson KD: Nonsuppressible insulin-like activity and thyroid hormones: major pituitary-dependent sulfation factors for chick embryo cartilage. Proc Natl Acad Sci U S A 1976, 73(8):2904-2908.

11. Rinderknecht $E_{1}$, Humbel RE: Polypeptides with nonsuppressible insulinlike and cell-growth promoting activities in human serum: isolation, chemical characterization, and some biological properties of forms I and II. Proc Natl Acad Sci U S A 1976, 73(7):2365-2369.
12. Daughaday WH, Hall K, Salmon WD Jr, Van den Brande JL, Van Wyk JJ: On the nomenclature of the somatomedins and insulin-like growth factors. $J$ Clin Endocrinol Metab 1987, 65(5):1075-1076.

13. Clemmons DR: Role of insulin-like growth factor binding proteins in controlling IGF actions. Mol Cell Endocrinol 1998, 140(1-2):19-24.

14. Clemmons DR, Busby W, Clarke JB, Parker A, Duan C, Nam TJ: Modifications of insulin-like growth factor binding proteins and their role in controlling IGF actions. Endocr J 1998, 45(Suppl):S1-S8.

15. Annenkov A: The insulin-like growth factor (IGF) receptor type 1 (IGF1R) as an essential component of the signalling network regulating neurogenesis. Mol Neurobiol 2009, 40(3):195-215.

16. Chitnis MM, Yuen JS, Protheroe AS, Pollak M, Macaulay VM: The type 1 insulin-like growth factor receptor pathway. Clin Cancer Res 2008, 14(20):6364-6370.

17. LeRoith $D$, Werner $H$, Beitner-Johnson $D$, Roberts $C T$ Jr: Molecular and cellular aspects of the insulin-like growth factor I receptor. Endocr Rev 1995, 16(2):143-163.

18. D'Ercole AJ, Applewhite GT, Underwood LE: Evidence that somatomedin is synthesized by multiple tissues in the fetus. Dev Biol 1980, 75(2):315-328.

19. Rosenbloom AL, Guevara-Aguirre J, Rosenfeld RG, Pollock BH: Growth in growth hormone insensitivity. Trends in endocrinology and metabolism: TEM 1994, 5(7):296-303.

20. Ghigo MC, Torsello A, Grilli R, Luoni M, Guidi M, Cella SG, Locatelli V, Muller EE: Effects of GH and IGF-I administration on GHRH and somatostatin mRNA levels: I. A study on ad libitum fed and starved adult male rats. J Endocrinol Invest 1997, 20(3):144-150.

21. Berelowitz M, Szabo M, Frohman LA, Firestone S, Chu L, Hintz RL: Somatomedin- $\mathrm{C}$ mediates growth hormone negative feedback by effects on both the hypothalamus and the pituitary. Science 1981, 212(4500):1279-1281.

22. Bertherat J, Bluet-Pajot MT, Epelbaum J: Neuroendocrine regulation of growth hormone. Eur J Endocrinol 1995, 132(1):12-24.

23. Ohlsson C, Mohan S, Sjogren K, Tivesten A, Isgaard J, Isaksson O, Jansson JO, Svensson J: The role of liver-derived insulin-like growth factor-I. Endocr Rev 2009, 30(5):494-535.

24. Daughaday WH, Rotwein P: Insulin-like growth factors I and II. Peptide, messenger ribonucleic acid and gene structures, serum, and tissue concentrations. Endocr Rev 1989, 10(1):68-91.

25. Clemmons DR, Underwood LE: Nutritional regulation of IGF-I and IGF binding proteins. Annu Rev Nutr 1991, 11:393-412.

26. Murphy $\sqcup$, Friesen HG: Differential effects of estrogen and growth hormone on uterine and hepatic insulin-like growth factor I gene expression in the ovariectomized hypophysectomized rat. Endocrinology 1988, 122(1):325-332.

27. Adashi EY, Resnick CE, Hurwitz A, Ricciarelli E, Hernandez ER, Roberts CT, Leroith D, Rosenfeld R: Insulin-like growth factors: the ovarian connection. Hum Reprod 1991, 6(9):1213-1219.

28. Cohick WS, Clemmons DR: The insulin-like growth factors. Annu Rev Physiol 1993, 55:131-153.

29. Adamo M, Lowe WL Jr, LeRoith D, Roberts CT Jr: Insulin-like growth factor I messenger ribonucleic acids with alternative 5'-untranslated regions are differentially expressed during development of the rat. Endocrinology 1989, 124(6):2737-2744.

30. Wolf E, Hoeflich A, Lahm H: What is the function of IGF-II in postnatal life? Answers from transgenic mouse models. Growth Horm IGF Res 1998, 8(3):185-193.

31. Zhou Y, Xu BC, Maheshwari HG, He L, Reed M, Lozykowski M, Okada S, Cataldo L, Coschigamo K, Wagner TE, et al: A mammalian model for Laron syndrome produced by targeted disruption of the mouse growth hormone receptor/binding protein gene (the Laron mouse). Proc Natl Acad Sci U S A 1997, 94(24):13215-13220.

32. Wit $\mathrm{JM}$, van Unen $\mathrm{H}$ : Growth of infants with neonatal growth hormone deficiency. Arch Dis Child 1992, 67(7):920-924.

33. Savage MO, Blum WF, Ranke MB, Postel-Vinay MC, Cotterill AM, Hall K, Chatelain PG, Preece MA, Rosenfeld RG: Clinical features and endocrine status in patients with growth hormone insensitivity (laron syndrome). J Clin Endocrinol Metab 1993, 77(6):1465-1471.

34. Laron Z: Laron syndrome-primary growth hormone resistance. In Hormone resistance syndromes contemporary endocrinology. Edited by Jameson JL. NJ: Humana Press; 1999:17-37. vol. 2. 
35. Savage MO, Burren CP, Blair JC, Woods KA, Metherell L, Clark AJ, CamachoHubner C: Growth hormone insensitivity: pathophysiology, diagnosis, clinical variation and future perspectives. Horm Res 2001, 55(Suppl 2):32-35.

36. Lupu F, Terwilliger JD, Lee K, Segre GV, Efstratiadis A: Roles of growth hormone and insulin-like growth factor 1 in mouse postnatal growth. Dev Biol 2001, 229(1):141-162.

37. Baker J, Liu JP, Robertson EJ, Efstratiadis A: Role of insulin-like growth factors in embryonic and postnatal growth. Cell 1993, 75(1):73-82.

38. Liu JP, Baker J, Perkins AS, Robertson EJ, Efstratiadis A: Mice carrying null mutations of the genes encoding insulin-like growth factor I (Igf-1) and type 1 IGF receptor (Igf1r). Cell 1993, 75(1):59-72.

39. Abuzzahab MJ, Schneider A, Goddard A, Grigorescu F, Lautier C, Keller E, Kiess W, Klammt J, Kratzsch J, Osgood D, et al: IGF-I receptor mutations resulting in intrauterine and postnatal growth retardation. N Eng J Med 2003, 349(23):2211-2222

40. Woods KA, Camacho-Hubner C, Savage MO, Clark AJ: Intrauterine growth retardation and postnatal growth failure associated with deletion of the insulin-like growth factor I gene. N Eng J Med 1996, 335(18):1363-1367.

41. Leal Ade C, Canton AP, Montenegro LR, Coutinho DC, Arnhold IJ, Jorge AA: Mutations in insulin-like growth factor receptor 1 gene (IGF1R) resulting in intrauterine and postnatal growth retardation. Arq Bras Endocrinol Metabol 2011, 55(8):541-549.

42. Daughaday WH: Growth hormone and the somatomedins. In Endocrine control of growth. Edited by Daughaday WH. New York: Elsevier; 1981:1-24.

43. Savage MO, Attie KM, David A, Metherell LA, Clark AJ, Camacho-Hubner C: Endocrine assessment, molecular characterization and treatment of growth hormone insensitivity disorders. Nat Clin Pract Endocrinol Metab 2006, 2(7):395-407.

44. Backeljauw PF, Underwood LE, syndrome GCGGhi: Therapy for 6.5-7.5 years with recombinant insulin-like growth factor I in children with growth hormone insensitivity syndrome: a clinical research center study. J Clin Endocrinol Metab 2001, 86(4):1504-1510.

45. D'Ercole AJ, Stiles AD, Underwood LE: Tissue concentrations of somatomedin C: further evidence for multiple sites of synthesis and paracrine or autocrine mechanisms of action. Proc Natl Acad Sci U S A 1984, 81(3):935-939.

46. Froesch ER, Schmid C, Schwander J, Zapf J: Actions of insulin-like growth factors. Annu Rev Physiol 1985, 47:443-467.

47. Sjogren K, Liu JL, Blad K, Skrtic S, Vidal O, Wallenius V, LeRoith D, Tornell J, Isaksson OG, Jansson JO, et al: Liver-derived insulin-like growth factor I (IGF-I) is the principal source of IGF-I in blood but is not required for postnatal body growth in mice. Proc Natl Acad Sci U S A 1999, 96(12):7088-7092.

48. Yakar S, Rosen CJ, Bouxsein ML, Sun H, Mejia W, Kawashima Y, Wu Y, Emerton K, Williams V, Jepsen $\mathrm{K}$, et al: Serum complexes of insulin-like growth factor-1 modulate skeletal integrity and carbohydrate metabolism. FASEB J 2009, 23(3):709-719.

49. Chin E, Zhou J, Dai J, Baxter RC, Bondy CA: Cellular localization and regulation of gene expression for components of the insulin-like growth factor ternary binding protein complex. Endocrinology 1994, 134(6):2498-2504

50. Jaques G, Noll K, Wegmann B, Witten S, Kogan E, Radulescu RT, Havemann K: Nuclear localization of insulin-like growth factor binding protein 3 in a lung cancer cell line. Endocrinology 1997, 138(4):1767-1770.

51. Schedlich $L$, Le Page SL, Firth SM, Briggs $L$, Jans DA, Baxter RC: Nuclear import of insulin-like growth factor-binding protein-3 and -5 is mediated by the importin beta subunit. J Biol Chem 2000, 275(31):23462-23470.

52. Lee KW, Ma L, Yan X, Liu B, Zhang XK, Cohen P: Rapid apoptosis induction by IGFBP-3 involves an insulin-like growth factor-independent nucleomitochondrial translocation of RXRalpha/Nur77. J Biol Chem 2005, 280(17):16942-16948.

53. Kenner KA, Heidenreich KA: Insulin and insulin-like growth factors stimulate in vivo receptor autophosphorylation and tyrosine phosphorylation of a $70 \mathrm{~K}$ substrate in cultured fetal chick neurons. Endocrinology 1991, 129(1):301-311.

54. Begum N, Robinson LJ, Draznin B, Heidenreich KA: Protein phosphatase-1 and $-2 a$ activities in cultured fetal chick neurons: differential regulation by insulin and insulin-like growth factor-I. Endocrinology 1993, 133(5):2085-2090.

55. Garcia-Fernandez M, Delgado G, Puche JE, Gonzalez-Baron S, Castilla Cortazar I: Low doses of insulin-like growth factor I improve insulin resistance, lipid metabolism, and oxidative damage in aging rats. Endocrinology 2008, 149(5):2433-2442.

56. Puche JE, Garcia-Fernandez M, Muntane J, Rioja J, Gonzalez-Baron S, Castilla Cortazar I: Low doses of insulin-like growth factor-I induce mitochondrial protection in aging rats. Endocrinology 2008, 149(5):2620-2627.

57. Garcia-Fernandez M, Sierra I, Puche JE, Guerra L, Castilla-Cortazar I: Liver mitochondrial dysfunction is reverted by insulin-like growth factor II (IGF-II) in aging rats. J Trans/ Med 2011, 9:123.

58. Castilla-Cortazar I, Garcia-Fernandez M, Delgado G, Puche JE, Sierra I, Barhoum R, Gonzalez-Baron S: Hepatoprotection and neuroprotection induced by low doses of IGF-II in aging rats. J Trans/ Med 2011, 9:103.

59. Joseph D'Ercole A, Ye P: Expanding the mind: insulin-like growth factor I and brain development. Endocrinology 2008, 149(12):5958-5962.

60. Drago J, Murphy M, Carroll SM, Harvey RP, Bartlett PF: Fibroblast growth factor-mediated proliferation of central nervous system precursors depends on endogenous production of insulin-like growth factor I. Proc Natl Acad Sci U S A 1991, 88(6):2199-2203.

61. Popken GJ, Dechert-Zeger M, Ye P, D'Ercole AJ: Brain development. Adv Exp Med Biol 2005, 567:187-220.

62. Brooker GJ, Kalloniatis M, Russo VC, Murphy M, Werther GA, Bartlett PF: Endogenous IGF-1 regulates the neuronal differentiation of adult stem cells. J Neurosci Res 2000, 59(3):332-341.

63. Hsieh J, Aimone JB, Kaspar BK, Kuwabara T, Nakashima K, Gage FH: IGF-I instructs multipotent adult neural progenitor cells to become oligodendrocytes. J Cell Biol 2004, 164(1):111-122.

64. Reinhardt RR, Bondy CA: Insulin-like growth factors cross the blood-brain barrier. Endocrinology 1994, 135(5):1753-1761.

65. Rosenfeld RG, Pham H, Keller BT, Borchardt RT, Pardridge WM: Demonstration and structural comparison of receptors for insulin-like growth factor-I and -II (IGF-I and -II) in brain and blood-brain barrier. Biochem Biophys Res Commun 1987, 149(1):159-166.

66. Duffy KR, Pardridge WM, Rosenfeld RG: Human blood-brain barrier insulinlike growth factor receptor. Metab Clin Exp 1988, 37(2):136-140.

67. Nishijima T, Piriz J, Duflot S, Fernandez AM, Gaitan G, Gomez-Pinedo U, Verdugo JM, Leroy F, Soya $H$, Nunez A, et al: Neuronal activity drives localized blood-brain-barrier transport of serum insulin-like growth factor-I into the CNS. Neuron 2010, 67(5):834-846.

68. Carro E, Trejo JL, Gomez-Isla T, LeRoith D, Torres-Aleman I: Serum insulin-like growth factor I regulates brain amyloid-beta levels. Nat Med 2002, 8(12):1390-1397.

69. Backstrom M, Hall K, Sara V: Somatomedin levels in cerebrospinal fluid from adults with pituitary disorders. Acta Endocrinol 1984, 107(2):171-178.

70. Hynes MA, Van Wyk JJ, Brooks PJ, D'Ercole AJ, Jansen M, Lund PK: Growth hormone dependence of somatomedin-C/insulin-like growth factor-I and insulin-like growth factor-II messenger ribonucleic acids. Mol Endocrinol 1987, 1(3):233-242.

71. Chernausek SD: Insulin-like growth factor-I (IGF-I) production by astroglial cells: regulation and importance for epidermal growth factor-induced cell replication. J Neurosci Res 1993, 34(2):189-197.

72. Pons S, Torres-Aleman I: Basic fibroblast growth factor modulates insulinlike growth factor-l, its receptor, and its binding proteins in hypothalamic cell cultures. Endocrinology 1992, 131(5):2271-2278.

73. Lowe WL Jr, Adamo M, Werner H, Roberts CT Jr, LeRoith D: Regulation by fasting of rat insulin-like growth factor I and its receptor. Effects on gene expression and binding. J Clin Invest 1989, 84(2):619-626.

74. Hall KS, Lien B, Paulsen JE, Clausen OP, Bergan A, Rugstad HE: Effect of preoperative $4^{\prime}$-epidoxorubicin (epi-adriamycin) treatment on the regeneration and function of the liver in partially hepatectomized rats. European surgical research Europaische chirurgische Forschung Recherches chirurgicales europeennes 1989, 21(3-4):196-204.

75. Lee WH, Clemens JA, Bondy CA: Insulin-like growth factors in the response to cerebral ischemia. Mol Cell Neurosci 1992, 3(1):36-43.

76. Garcia-Estrada J, Garcia-Segura LM, Torres-Aleman I: Expression of insulinlike growth factor I by astrocytes in response to injury. Brain Res 1992, 592(1-2):343-347.

77. Yamaguchi F, Itano T, Miyamoto O, Janjua NA, Ohmoto T, Hosokawa K, Hatase O: Increase of extracellular insulin-like growth factor I (IGF-I) concentration following electrolytical lesion in rat hippocampus. Neurosci Lett 1991, 128(2):273-276.

78. Yao DL, West NR, Bondy CA, Brenner M, Hudson LD, Zhou J, Collins GH, Webster HD: Cryogenic spinal cord injury induces astrocytic gene expression of insulin-like growth factor I and insulin-like growth factor 
binding protein 2 during myelin regeneration. J Neurosci Res 1995, 40(5):647-659.

79. Komoly S, Hudson LD, Webster HD, Bondy CA: Insulin-like growth factor I gene expression is induced in astrocytes during experimental demyelination. Proc Natl Acad Sci U S A 1992, 89(5):1894-1898.

80. Yao DL, Liu X, Hudson LD, Webster HD: Insulin-like growth factor I treatment reduces demyelination and up-regulates gene expression of myelin-related proteins in experimental autoimmune encephalomyelitis. Proc Natl Acad Sci U S A 1995, 92(13):6190-6194.

81. Liu X, Yao DL, Webster H: Insulin-like growth factor I treatment reduces clinical deficits and lesion severity in acute demyelinating experimental autoimmune encephalomyelitis. Mult Scler 1995, 1(1):2-9.

82. D'Ercole AJ, Ye P, Calikoglu AS, Gutierrez-Ospina G: The role of the insulinlike growth factors in the central nervous system. Mol Neurobiol 1996, 13(3):227-255

83. Behringer RR, Lewin TM, Quaife CJ, Palmiter RD, Brinster RL, D'Ercole AJ: Expression of insulin-like growth factor I stimulates normal somatic growth in growth hormone-deficient transgenic mice. Endocrinology 1990, 127(3):1033-1040.

84. Carson MJ, Behringer RR, Brinster RL, McMorris FA: Insulin-like growth factor I increases brain growth and central nervous system myelination in transgenic mice. Neuron 1993, 10(4):729-740.

85. Beck KD, Powell-Braxton L, Widmer HR, Valverde J, Hefti F: Igf1 gene disruption results in reduced brain size, CNS hypomyelination, and loss of hippocampal granule and striatal parvalbumin-containing neurons. Neuron 1995, 14(4):717-730.

86. Ye P, Li L, Richards RG, DiAugustine RP, D'Ercole AJ: Myelination is altered in insulin-like growth factor-I null mutant mice. J Neurosci 2002, 22(14):6041-6051.

87. Skrtic S, Wallenius V, Ekberg S, Brenzel A, Gressner AM, Jansson JO: Insulinlike growth factors stimulate expression of hepatocyte growth factor but not transforming growth factor beta1 in cultured hepatic stellate cells. Endocrinology 1997, 138(11):4683-4689.

88. Caro JF, Poulos J, Ittoop O, Pories WJ, Flickinger EG, Sinha MK: Insulin-like growth factor I binding in hepatocytes from human liver, human hepatoma, and normal, regenerating, and fetal rat liver. J Clin Invest 1988, 81(4):976-981.

89. Skrtic S, Waññenius $V$, Ekberg S, Brenzel A, Gressner AJOJ: Expression pattern of growth hormone/insulin-like growth factor associated genes in rat liver. In Cells of the hepatic sinusoid. Edited by Wisse E, Knook D, Balabaud C. The Netherlands: The Kupffer Foundation; 1997:131-133.

90. Brenzel A, Gressner AM: Characterization of insulin-like growth factor (IGF)-I-receptor binding sites during in vitro transformation of rat hepatic stellate cells to myofibroblasts. Eur J Clin Chem Clin: J Forum Eur Clin Chem Soc 1996, 34(5):401-409.

91. Pinzani M, Abboud HE, Aron DC: Secretion of insulin-like growth factor-I and binding proteins by rat liver fat-storing cells: regulatory role of platelet-derived growth factor. Endocrinology 1990, 127(5):2343-2349.

92. Gressner AM, Brenzel A, Vossmeyer T: Hepatocyte-conditioned medium potentiates insulin-like growth factor (IGF) 1 and 2 stimulated DNA synthesis of cultured fat storing cells. Liver 1993, 13(2):86-94.

93. Yakar S, Liu JL, Stannard B, Butler A, Accili D, Sauer B, LeRoith D: Normal growth and development in the absence of hepatic insulin-like growth factor I. Proc Natl Acad Sci U S A 1999, 96(13):7324-7329.

94. Sjogren K, Bohlooly YM, Olsson B, Coschigano K, Tornell J, Mohan S, Isaksson OG, Baumann G, Kopchick J, Ohlsson C: Disproportional skeletal growth and markedly decreased bone mineral content in growth hormone receptor -/- mice. Biochem Biophys Res Commun 2000, 267(2):603-608.

95. Shea BT, Hammer RE, Brinster RL: Growth allometry of the organs in giant transgenic mice. Endocrinology 1987, 121(6):1924-1930.

96. Quaife CJ, Mathews LS, Pinkert CA, Hammer RE, Brinster RL, Palmiter RD: Histopathology associated with elevated levels of growth hormone and insulin-like growth factor I in transgenic mice. Endocrinology 1989, 124(1):40-48.

97. Pennisi PA, Kopchick JJ, Thorgeirsson S, LeRoith D, Yakar S: Role of growth hormone (GH) in liver regeneration. Endocrinology 2004, 145(10):4748-4755.

98. Desbois-Mouthon C, Wendum D, Cadoret A, Rey C, Leneuve P, Blaise A, Housset C, Tronche F, Le Bouc Y, Holzenberger M: Hepatocyte proliferation during liver regeneration is impaired in mice with liver-specific IGF-1R knockout. FASEB J 2006, 20(6):773-775.
99. Fausto N, Laird AD, Webber EM: Liver regeneration. 2. Role of growth factors and cytokines in hepatic regeneration. FASEB J 1995, 9(15):1527-1536.

100. Cressman DE, Greenbaum LE, DeAngelis RA, Ciliberto G, Furth EE, Poli V, Taub R: Liver failure and defective hepatocyte regeneration in interleukin-6-deficient mice. Science 1996, 274(5291):1379-1383.

101. Silva JR, Figueiredo JR, van den Hurk R: Involvement of growth hormone $(\mathrm{GH})$ and insulin-like growth factor (IGF) system in ovarian folliculogenesis. Theriogenology 2009, 71(8):1193-1208.

102. Adashi EY: The IGF family and folliculogenesis. J Reprod Immunol 1998, 39(1-2):13-19.

103. Zhao J, Taverne MA, Van Der Weijden GC, Bevers MM, Van Den Hurk R: Insulin-like growth factor-I (IGF-I) stimulates the development of cultured rat pre-antral follicles. Mol Reprod Dev 2001, 58(3):287-296.

104. Zhao J, Taverne MA, van der Weijden GC, Bevers MM, van den Hurk R: Immunohistochemical localisation of growth hormone $(\mathrm{GH}), \mathrm{GH}$ receptor (GHR), insulin-like growth factor I (IGF-I) and type I IGF-I receptor, and gene expression of GH and GHR in rat pre-antral follicles. Zygote 2002, 10(1):85-94

105. Demeestere I, Gervy C, Centner J, Devreker F, Englert Y, Delbaere A: Effect of insulin-like growth factor-I during preantral follicular culture on steroidogenesis, in vitro oocyte maturation, and embryo development in mice. Biol Reprod 2004, 70(6):1664-1669.

106. Zhou J, Kumar TR, Matzuk MM, Bondy C: Insulin-like growth factor I regulates gonadotropin responsiveness in the murine ovary. $\mathrm{Mol}$ Endocrinol 1997, 11(13):1924-1933.

107. Monget $P$, Fabre $S$, Mulsant $P$, Lecerf F, Elsen JM, Mazerbourg S, Pisselet $C$, Monniaux D: Regulation of ovarian folliculogenesis by IGF and BMP system in domestic animals. Domest Anim Endocrinol 2002, 23(1-2):139-154.

108. Giudice LC: Insulin-like growth factors and ovarian follicular development. Endocr Rev 1992, 13(4):641-669.

109. Magoffin DA, Weitsman SR: Insulin-like growth factor-I regulation of luteinizing hormone $(\mathrm{LH})$ receptor messenger ribonucleic acid expression and LH-stimulated signal transduction in rat ovarian thecainterstitial cells. Biol Reprod 1994, 51(4):766-775.

110. Tsuchiya M, Minegishi T, Kishi H, Tano M, Kameda T, Hirakawa T, Ibuki Y, Mizutani T, Miyamoto K: Control of the expression of luteinizing hormone receptor by local factors in rat granulosa cells. Arch Biochem Biophys 1999, 367(2):185-192.

111. Yu Y, Yan J, Li M, Yan L, Zhao Y, Lian Y, Li R, Liu P, Qiao J: Effects of combined epidermal growth factor, brain-derived neurotrophic factor and insulin-like growth factor-1 on human oocyte maturation and early fertilized and cloned embryo development. Hum Reprod 2012, 27(7):2146-2159.

112. Stanek MB, Borman SM, Molskness TA, Larson JM, Stouffer RL, Patton PE: Insulin and insulin-like growth factor stimulation of vascular endothelial growth factor production by luteinized granulosa cells: comparison between polycystic ovarian syndrome (PCOS) and nonPCOS women. J Clin Endocrinol Metab 2007, 92(7):2726-2733.

113. Hall P: Testicular steroid synthesis: organization and regulation. In The physiology of reproduction. Edited by Knobil E, Neill J. New York: Raven Press; 1994:1335-1362. vol. 1.

114. Rouiller-Fabre V, Lecref L, Gautier C, Saez JM, Habert R: Expression and effect of insulin-like growth factor I on rat fetal Leydig cell function and differentiation. Endocrinology 1998, 139(6):2926-2934.

115. Saez J, Lejeune $H$ : Regulation of Leydig cell function by hormones and growth factors other than LH and IGF-I. In The leydig cell. Edited by Payne A, Hardy M, Russell L. Vienna: Cache River Press; 1996:383-406. vol. 1.

116. Vannelli BG, Barni T, Orlando C, Natali A, Serio M, Balboni GC: Insulin-like growth factor-I (IGF-I) and IGF-I receptor in human testis: an immunohistochemical study. Fertil Steril 1988, 49(4):666-669.

117. Cailleau J, Vermeire S, Verhoeven G: Independent control of the production of insulin-like growth factor I and its binding protein by cultured testicular cells. Mol Cell Endocrinol 1990, 69(1):79-89.

118. Naville D, Chatelain PG, Avallet O, Saez JM: Control of production of insulin-like growth factor I by pig Leydig and Sertoli cells cultured alone or together. Cell-cell interactions. Mol Cell Endocrinol 1990, 70(3):217-224

119. Spiteri-Grech J, Bartlett JM, Nieschlag E: Regulation of testicular insulin-like growth factor-I in pubertal growth hormone-deficient male rats. J Endocrinol 1991, 131(2):279-285.

120. Perrard-Sapori MH, Chatelain PG, Jaillard C, Saez JM: Characterization and regulation of somatomedin-C/insulin-like growth factor I (Sm-C/IGF-I) 
receptors on cultured pig Leydig cells. Effects of Sm-C/IGF-I on luteotropin receptors and steroidogenesis. Eur J Biochem / FEBS 1987, 165(1):209-214.

121. Lin T, Haskell J, Vinson N, Terracio L: Characterization of insulin and insulin-like growth factor I receptors of purified Leydig cells and their role in steroidogenesis in primary culture: a comparative study. Endocrinology 1986, 119(4):1641-1647.

122. Saez JM: Leydig cells: endocrine, paracrine, and autocrine regulation. Endocr Rev 1994, 15(5):574-626.

123. Lin T: Insulin-like growth factor-I regulation of the leydig cell. In The leyding cell. Edited by Payne A, Hardy M, Russell L. Vienna: Cache River Press; 1996:477-491. vol. 1.

124. Baker J, Hardy MP, Zhou J, Bondy C, Lupu F, Bellve AR, Efstratiadis A: Effects of an Igf1 gene null mutation on mouse reproduction. Mol Endocrinol 1996, 10(7):903-918.

125. Gelber SJ, Hardy MP, Mendis-Handagama SM, Casella SJ: Effects of insulinlike growth factor-I on androgen production by highly purified pubertal and adult rat Leydig cells. J Androl 1992, 13(2):125-130.

126. Adashi EY, Resnick CE, Hurwitz A, Ricciardelli E, Hernandez ER, Roberts CT, LeRoith D, Rosenfeld R: The ovarian and testicular IGF-I system: a comparative analysis. In Spermatogenesis-Fertilization-Contraception: Molecular, Cellular and Endocrine Events in Male Reproduction. Edited by Nieschlag E, Habenicht UF. Berlin: Springer-Verlag; 1992:143-168.

127. Giudice LC, Saleh W: Growth factors in reproduction. Trends in endocrinology and metabolism: TEM 1995, 6(2):60-69.

128. Nef S, Verma-Kurvari S, Merenmies J, Vassalli JD, Efstratiadis A, Accili D, Parada LF: Testis determination requires insulin receptor family function in mice. Nature 2003, 426(6964):291-295.

129. Villalpando I, Lopez-Olmos V: Insulin-like growth factor I (IGF-I) regulates endocrine activity of the embryonic testis in the mouse. J Steroid Biochem Mol Biol 2003, 86(2):151-158.

130. Tapanainen J, Kuopio T, Pelliniemi LJ, Huhtaniemi I: Rat testicular endogenous steroids and number of leydig cells between the fetal period and sexual maturity. Biol Reprod 1984, 31(5):1027-1035.

131. Lin T, Blaisdell J, Haskell JF: Type I IGF receptors of leydig cells are upregulated by human chorionic gonadotropin. Biochem Biophys Res Commun 1987, 149(3):852-858.

132. Moore A, Morris ID: The involvement of insulin-like growth factor-I in local control of steroidogenesis and DNA synthesis of leydig and non-leydig cells in the rat testicular interstitium. J Endocrino/ 1993, 138(1):107-114.

133. Chuzel F, Clark AM, Avallet O, Saez JM: Transcriptional regulation of the lutropin/human choriogonadotropin receptor and three enzymes of steroidogenesis by growth factors in cultured pig leydig cells. European journal of biochemistry/FEBS 1996, 239(1):8-16.

134. Tiong TS, Herington AC: Tissue distribution, characterization, and regulation of messenger ribonucleic acid for growth hormone receptor and serum binding protein in the rat. Endocrinology 1991, 129(3):1628-1634.

135. Lobie PE, Breipohl W, Aragon JG, Waters MJ: Cellular localization of the growth hormone receptor/binding protein in the male and female reproductive systems. Endocrinology 1990, 126(4):2214-2221.

136. Godfrey P, Rahal JO, Beamer WG, Copeland NG, Jenkins NA, Mayo KE: GHRH receptor of little mice contains a missense mutation in the extracellular domain that disrupts receptor function. Nat Genet 1993, 4(3):227-232.

137. Chubb C: Sexual behavior and fertility of little mice. Biol Reprod 1987, 37(3):564-569.

138. Bach LA: The insulin-like growth factor system in kidney disease and hypertension. Curr Opin Nephrol Hypertens 2012, 21(1):86-91.

139. Rabkin R, Schaefer F: New concepts: growth hormone, insulin-like growth factor-I and the kidney. Growth Horm IGF Res 2004, 14(4):270-276.

140. Bridgewater DJ, Dionne JM, Butt MJ, Pin CL, Matsell DG: The role of the type I insulin-like growth factor receptor (IGF-IR) in glomerular integrity. Growth Horm IGF Res 2008, 18(1):26-37.

141. Martin AA, Tomas FM, Owens PC, Knowles SE, Ballard FJ, Read LC: IGF-I and its variant, des-(1-3)IGF-I, enhance growth in rats with reduced renal mass. Am J Physiol 1991, 261(4 Pt 2):F626-F633.

142. Hirschberg R: Insulin-like growth factor I in the kidney. Miner Electrolyte Metab 1996, 22(1-3):128-132.

143. Kumar PA, Brosius FC III, Menon RK: The glomerular podocyte as a target of growth hormone action: implications for the pathogenesis of diabetic nephropathy. Curr Diabetes Rev 2011, 7(1):50-55.
144. Yildiz B, Kural N, Colak O, Ak I, Akcar N: IGF-1, IGFBP-3, VEGF and MMP-9 levels and their potential relationship with renal functions in patients with compensatory renal growth. Clin Physiol Funct Imaging 2008, 28(2):107-112.

145. Mulroney SE, Haramati A, Werner H, Bondy C, Roberts CT Jr, LeRoith D: Altered expression of insulin-like growth factor-I (IGF-I) and IGF receptor genes after unilateral nephrectomy in immature rats. Endocrinology 1992, 130(1):249-256

146. Landau D, Biada J, Chen Y, Sood S, Yakar S, Leroith D, Segev Y, Rabkin R: A marked deficiency in circulating and renal IGF-I peptide does not inhibit compensatory renal enlargement in uninephrectomized mice. Growth Horm IGF Res 2011, 21(5):279-284.

147. Delafontaine $P$, Bernstein KE, Alexander RW: Insulin-like growth factor I gene expression in vascular cells. Hypertension 1991, 17(5):693-699.

148. Guler HP, Zapf J, Scheiwiller E, Froesch ER: Recombinant human insulinlike growth factor I stimulates growth and has distinct effects on organ size in hypophysectomized rats. Proc Natl Acad Sci U S A 1988 85(13):4889-4893.

149. Wickman A, Isgaard J, Adams MA, Friberg P: Inhibition of nitric oxide in rats. Regulation of cardiovascular structure and expression of insulin-like growth factor I and its receptor messenger RNA. J Hypertens 1997, 15(7):751-759.

150. Chisalita SI, Johansson GS, Liefvendahl E, Back K, Arnqvist HJ: Human aortic smooth muscle cells are insulin resistant at the receptor level but sensitive to IGF1 and IGF2. J Mol Endocrinol 2009, 43(6):231-239.

151. Johansson GS, Chisalita SI, Arnqvist HJ: Human microvascular endothelial cells are sensitive to IGF-I but resistant to insulin at the receptor level. Mol Cell Endocrinol 2008, 296(1-2):58-63.

152. Pete G, Hu Y, Walsh M, Sowers J, Dunbar JC: Insulin-like growth factor-I decreases mean blood pressure and selectively increases regional blood flow in normal rats. Exp Biol Med 1996, 213(2):187-192.

153. Walsh MF, Barazi M, Pete G, Muniyappa R, Dunbar JC, Sowers JR: Insulin-like growth factor I diminishes in vivo and in vitro vascular contractility: role of vascular nitric oxide. Endocrinology 1996, 137(5):1798-1803.

154. Copeland KC, Nair KS: Recombinant human insulin-like growth factor-I increases forearm blood flow. J Clin Endocrinol Metab 1994, 79(1):230-232

155. Delafontaine $\mathrm{P}$, Song YH, Li Y: Expression, regulation, and function of IGF1, IGF-1R, and IGF-1 binding proteins in blood vessels. Arterioscler Thromb Vasc Biol 2004, 24(3):435-444.

156. Smith TJ: Insulin-like growth factor-I regulation of immune function: a potential therapeutic target in autoimmune diseases? Pharmacol Rev 2010, 62(2):199-236.

157. O'Connor JC, McCusker RH, Strle K, Johnson RW, Dantzer R, Kelley KW: Regulation of IGF-I function by proinflammatory cytokines: at the interface of immunology and endocrinology. Cell Immunol 2008, 252(1-2):91-110

158. Tsarfaty G, Longo DL, Murphy WJ: Human insulin-like growth factor I exerts hematopoietic growth-promoting effects after in vivo administration. Exp Hematol 1994, 22(13):1273-1277.

159. Murphy WJ, Durum SK, Longo DL: Human growth hormone promotes engraftment of murine or human T cells in severe combined immunodeficient mice. Proc Natl Acad Sci U S A 1992, 89(10):4481-4485

160. Murphy WJ, Durum SK, Longo DL: Role of neuroendocrine hormones in murine T cell development. Growth hormone exerts thymopoietic effects in vivo. Journal of immunology 1992, 149(12):3851-3857.

161. de Mello-Coelho V, Villa-Verde DM, Dardenne M, Savino W: Pituitary hormones modulate cell-cell interactions between thymocytes and thymic epithelial cells. J Neuroimmunol 1997, 76(1-2):39-49.

162. Hinton PS, Peterson CA, Dahly EM, Ney DM: IGF-I alters lymphocyte survival and regeneration in thymus and spleen after dexamethasone treatment. Am J Physiol 1998, 274(4 Pt 2):R912-R920.

163. Walsh PT, Smith LM, O'Connor R: Insulin-like growth factor-1 activates Akt and Jun N-terminal kinases (JNKs) in promoting the survival of $\mathrm{T}$ lymphocytes. Immunology 2002, 107(4):461-471.

164. Tu W, Cheung PT, Lau YL: Insulin-like growth factor 1 promotes cord blood $\mathrm{T}$ cell maturation and inhibits its spontaneous and phytohemagglutinin-induced apoptosis through different mechanisms. J Immunol 2000, 165(3):1331-1336.

165. Hunt P, Eardley DD: Suppressive effects of insulin and insulin-like growth factor-1 (IGF1) on immune responses. J Immunol 1986, 136(11):3994-3999. 
166. Gibson LF, Piktel D, Landreth KS: Insulin-like growth factor-1 potentiates expansion of interleukin-7-dependent pro-B cells. Blood 1993, 82(10):3005-3011.

167. Hadden JW, Malec PH, Coto J, Hadden EM: Thymic involution in aging. Prospects for correction. Ann N Y Acad Sci 1992, 673:231-239.

168. Miller RA: The aging immune system: primer and prospectus. Science 1996, 273(5271):70-74.

169. Lamberts SW, van den Beld AW, van der Lely AJ: The endocrinology of aging. Science 1997, 278(5337):419-424.

170. Chu YW, Schmitz S, Choudhury B, Telford W, Kapoor V, Garfield S, Howe D, Gress RE: Exogenous insulin-like growth factor 1 enhances thymopoiesis predominantly through thymic epithelial cell expansion. Blood 2008 112(7):2836-2846

171. Landreth KS, Narayanan R, Dorshkind K: Insulin-like growth factor-I regulates pro-B cell differentiation. Blood 1992, 80(5):1207-1212.

172. Jardieu P, Clark R, Mortensen D, Dorshkind K: In vivo administration of insulin-like growth factor-I stimulates primary B lymphopoiesis and enhances lymphocyte recovery after bone marrow transplantation. J Immunol 1994, 152(9):4320-4327.

173. Clark R: The somatogenic hormones and insulin-like growth factor-1: stimulators of lymphopoiesis and immune function. Endocr Rev 1997, 18(2):157-179.

174. Robbins K, McCabe S, Scheiner T, Strasser J, Clark R, Jardieu P. Immunological effects of insulin-like growth factor-I-enhancement of immunoglobulin synthesis. Clin Exp Immunol 1994, 95(2):337-342.

175. Rom WN, Paakko P: Activated alveolar macrophages express the insulinlike growth factor-I receptor. Am J Respir Cell Mol Biol 1991, 4(5):432-439.

176. Resnik R: Intrauterine growth restriction. Obstet Gynecol 2002, 99(3):490-496

177. Low JA, Handley-Derry MH, Burke SO, Peters RD, Pater EA, Killen HL, Derrick EJ: Association of intrauterine fetal growth retardation and learning deficits at age 9 to 11 years. Am J Obstet Gynecol 1992, 167(6):1499-1505.

178. Kramer MS, Olivier M, McLean FH, Willis DM, Usher RH: Impact of intrauterine growth retardation and body proportionality on fetal and neonatal outcome. Pediatrics 1990, 86(5):707-713.

179. Hattersley AT, Tooke JE: The fetal insulin hypothesis: an alternative explanation of the association of low birthweight with diabetes and vascular disease. Lancet 1999, 353(9166):1789-1792.

180. Barker DJ: The developmental origins of well-being. Philos Trans R SOC Lond B Biol Sci 2004, 359(1449):1359-1366.

181. Rosenfeld RG, Rosenbloom AL, Guevara-Aguirre J: Growth hormone (GH) insensitivity due to primary GH receptor deficiency. Endocr Rev 1994 15(3):369-390.

182. Randhawa $R$, Cohen $P$ : The role of the insulin-like growth factor system in prenatal growth. Mol Genet Metab 2005, 86(1-2):84-90

183. Gluckman PD, Hanson MA: Maternal constraint of fetal growth and its consequences. Semin Fetal Neonatal Med 2004, 9(5):419-425.

184. Penrose LS: Data on the genetics of birth weight. Ann Eugen 1952, 16(4):378-381

185. Setia S, Sridhar MG: Changes in GH/IGF-1 axis in intrauterine growth retardation: consequences of fetal programming? Hormone and metabolic research $=$ Hormon - und Stoffwechselforschung $=$ Hormones et metabolisme 2009, 41(11):791-798.

186. Brosens JJ, Pijnenborg R, Brosens IA: The myometrial junctional zone spiral arteries in normal and abnormal pregnancies: a review of the literature. Am J Obstet Gynecol 2002, 187(5):1416-1423.

187. Miller HC: Prenatal factors affecting intrauterine growth retardation. Clin Perinatol 1985, 12(2):307-318.

188. Voigt HJ, Becker V: Doppler flow measurements and histomorphology of the placental bed in uteroplacental insufficiency. J Perinat Med 1992, 20(2):139-147.

189. Verhaeghe J, Bougoussa M, Van Herck E, de Zegher F, Hennen G, Igout A: Placental growth hormone and IGF-I in a pregnant woman with Pit-1 deficiency. Clin Endocrinol 2000, 53(5):645-647.

190. Reece EA, Wiznitzer A, Le E, Homko CJ, Behrman H, Spencer EM: The relation between human fetal growth and fetal blood levels of insulinlike growth factors I and II, their binding proteins, and receptors. Obstet Gynecol 1994, 84(1):88-95.

191. Koutsaki M, Sifakis S, Zaravinos A, Koutroulakis D, Koukoura O, Spandidos DA: Decreased placental expression of hPGH, IGF-I and IGFBP-1 in pregnancies complicated by fetal growth restriction. Growth Horm IGF Res 2011, 21(1):31-36.
192. de Zegher F, Francois I, van Helvoirt M, Van den Berghe G: Clinical review 89: Small as fetus and short as child: from endogenous to exogenous growth hormone. J Clin Endocrinol Metab 1997, 82(7):2021-2026.

193. Giudice LC, de Zegher F, Gargosky SE, Dsupin BA, de las Fuentes L, Crystal RA, Hintz RL, Rosenfeld RG: Insulin-like growth factors and their binding proteins in the term and preterm human fetus and neonate with normal and extremes of intrauterine growth. J Clin Endocrinol Metab 1995, 80(5):1548-1555.

194. Kajimura S, Aida K, Duan C: Insulin-like growth factor-binding protein1 (IGFBP-1) mediates hypoxia-induced embryonic growth and developmental retardation. Proc Natl Acad Sci U S A 2005, 102(4):1240-1245.

195. Woods KA, van Helvoirt M, Ong KK, Mohn A, Levy J, de Zegher F, Dunger DB: The somatotropic axis in short children born small for gestational age: relation to insulin resistance. Pediatr Res 2002, 51(1):76-80

196. Jaquet D, Vidal H, Hankard R, Czernichow P, Levy-Marchal C: Impaired regulation of glucose transporter 4 gene expression in insulin resistance associated with in utero undernutrition. J Clin Endocrinol Metab 2001, 86(7):3266-3271.

197. Han VK, Carter AM: Control of growth and development of the fetoplacental unit. Curr Opin Pharmacol 2001, 1(6):632-640.

198. Vehaskari VM, Aviles DH, Manning J: Prenatal programming of adult hypertension in the rat. Kidney Int 2001, 59(1):238-245.

199. Laron Z, Pertzelan A, Mannheimer S: Genetic pituitary dwarfism with high serum concentation of growth hormone-a new inborn error of metabolism? Israel J Med Sci 1966, 2(2):152-155.

200. Laron Z: Laron syndrome (primary growth hormone resistance or insensitivity): the personal experience 1958-2003. J Clin Endocrinol Metab 2004, 89(3):1031-1044.

201. Lessons from Laron Syndrome (LS) 1996-1992. In Pediatr Adolesc Endocrinol, Volume 24. Edited by Laron Z, Parks JS. Basel: Karger; 1993:237-243.

202. Rosenbloom AL: Growth hormone insensitivity: physiologic and genetic basis, phenotype, and treatment. J Pediatr 1999, 135(3):280-289.

203. Feinberg MS, Scheinowitz M, Laron Z: Echocardiographic dimensions and function in adults with primary growth hormone resistance (laron syndrome). Am J Cardiol 2000, 85(2):209-213.

204. Brat O, Ziv I, Klinger B, Avraham M, Laron Z: Muscle force and endurance in untreated and human growth hormone or insulin-like growth factor-Itreated patients with growth hormone deficiency or laron syndrome. Horm Res 1997, 47(2):45-48.

205. Guevara-Aguirre J, Rosenbloom AL, Vaccarello MA, Fielder PJ, de la Vega A Diamond FB Jr, Rosenfeld RG: Growth hormone receptor deficiency (laron syndrome): clinical and genetic characteristics. Acta Paediatr Scand Supp/ 1991, 377:96-103.

206. Laron Z: Laron-type dwarfism (hereditary somatomedin deficiency): a review. In Advances in internal medicine and pediatrics. Edited by Frick $\mathrm{P}$, von Harnack GA, Kochsieck K, Martini GA, Prader A. Berlin: Springer; 1984:117-150

207. Lurie R, Ben-Amitai D, Laron Z: Laron syndrome (primary growth hormone insensitivity): a unique model to explore the effect of insulin-like growth factor 1 deficiency on human hair. Dermatology 2004, 208(4):314-318.

208. Johnston LB, Woods KA, Rose SJ, Clark AJ, Savage MO: The broad spectrum of inherited growth hormone insensitivity syndrome. Trends Endocrin Met: TEM 1998, 9(6):228-232.

209. Quiroga J, Beloqui O, Castilla A: Cirrhosis. In Hepatobilliary diseases. Edited by Prieto J, Rodes J, Shafritz DA. Berlin: Springer-Verlag; 1992:323-415.

210. Bruguera-Cortada M, Rodes-Teixidor J: Cirrosis hepática compensada. In Tratamiento de las enfermedades hepáticas. Edited by Bruguera-Cortada M, Mino-Fugarolas G, Pons-Romero F, Moreno-Otero R. Spain: Asociación Española para el Estudio del Hígado; 1997:45-50

211. Gines P, Quintero E, Arroyo V, Teres J, Bruguera M, Rimola A, Caballeria J, Rodes J, Rozman C: Compensated cirrhosis: natural history and prognostic factors. Hepatology 1987, 7(1):122-128.

212. Sheppard MS, Minuk GY, Bhaumick B, Bala RM: Insulin-like growth factors (IGF) in liver disease: differential changes of IGF-I and IGF-II. Clin Invest Med Medecine clinique et experimentale 1987, 10(2):49-53.

213. Caufriez A, Reding P, Urbain D, Golstein J, Copinschi G: Insulin-like growth factor I: a good indicator of functional hepatocellular capacity in alcoholic liver cirrhosis. J Endocrinol Invest 1991, 14(4):317-321. 
214. Assy N, Hochberg Z, Amit T, Shen-Orr Z, Enat R, Baruch Y: Growth hormone-stimulated insulin-like growth factor (IGF) I and IGF-binding protein-3 in liver cirrhosis. J Hepatol 1997, 27(5):796-802

215. Caregaro L, Alberino F, Amodio P, Merkel C, Angeli P, Plebani M, Bolognesi M, Gatta A: Nutritional and prognostic significance of insulin-like growth factor 1 in patients with liver cirrhosis. Nutrition 1997, 13(3):185-190.

216. Chang TC, Lin JJ, Yu SC, Chang TJ: Absence of growth-hormone receptor in hepatocellular carcinoma and cirrhotic liver. Hepatology 1990, 11(1):123-126.

217. Inaba T, Saito H, Inoue T, Han I, Furukawa S, Matsuda T, Ikeda S, Muto T: Growth hormone/insulin-like growth factor 1 axis alterations contribute to disturbed protein metabolism in cirrhosis patients after hepatectomy. J Hepatol 1999, 31(2):271-276.

218. Moller S, Becker U, Juul A, Skakkebaek NE, Christensen E: Prognostic value of insulinlike growth factor $I$ and its binding protein in patients with alcoholinduced liver disease. EMALD group. Hepatology 1996, 23(5):1073-1078.

219. Picardi A, de Oliveira AC, Muguerza B, Tosar A, Quiroga J, Castilla-Cortazar I, Santidrian S, Prieto J: Low doses of insulin-like growth factor-I improve nitrogen retention and food efficiency in rats with early cirrhosis. J Hepatol 1997, 26(1):191-202.

220. Pascual M, Castilla-Cortazar I, Urdaneta E, Quiroga J, Garcia M, Picardi A, Prieto J: Altered intestinal transport of amino acids in cirrhotic rats: the effect of insulin-like growth factor-I. Am J Physiol Gastrointest Liver Physiol 2000, 279(2):G319-G324

221. Castilla-Cortazar I, Prieto J, Urdaneta E, Pascual M, Nunez M, Zudaire E, Garcia M, Quiroga J, Santidrian S: Impaired intestinal sugar transport in cirrhotic rats: correction by low doses of insulin-like growth factor I. Gastroenterology 1997, 113(4):1180-1187.

222. Castilla-Cortazar I, Pascual M, Urdaneta E, Pardo J, Puche JE, Vivas B, DiazCasares A, Garcia M, Diaz-Sanchez M, Varela-Nieto I, et al: Jejunal microvilli atrophy and reduced nutrient transport in rats with advanced liver cirrhosis: improvement by insulin-like growth factor I. BMC Gastroenterol 2004, 4:12.

223. Castilla-Cortazar I, Garcia M, Muguerza B, Quiroga J, Perez R, Santidrian S, Prieto J: Hepatoprotective effects of insulin-like growth factor I in rats with carbon tetrachloride-induced cirrhosis. Gastroenterology 1997, 113(5):1682-1691.

224. Lorenzo-Zuniga V, Rodriguez-Ortigosa CM, Bartoli R, Martinez-Chantar ML, Martinez-Peralta L, Pardo A, Ojanguren I, Quiroga J, Planas R, Prieto J: Insulin-like growth factor I improves intestinal barrier function in cirrhotic rats. Gut 2006, 55(9):1306-1312.

225. Cemborain A, Castilla-Cortazar I, Garcia M, Quiroga J, Muguerza B, Picardi A Santidrian S, Prieto J: Osteopenia in rats with liver cirrhosis: beneficial effects of IGF-I treatment. J Hepatol 1998, 28(1):122-131.

226. Cemborain A, Castilla-Cortazar I, Garcia M, Muguerza B, Delgado G, DiazSanchez M, Picardi A: Effects of IGF-I treatment on osteopenia in rats with advanced liver cirrhosis. J Physiol Biochem 2000, 56(2):91-99.

227. Castilla-Cortazar I, Garcia M, Quiroga J, Diez N, Diez-Caballero F, Calvo A Diaz M, Prieto J: Insulin-like growth factor-I reverts testicular atrophy in rats with advanced cirrhosis. Hepatology 2000, 31(3):592-600.

228. Castilla-Cortazar I, Diez N, Garcia-Fernandez M, Puche JE, Diez-Caballero F, Quiroga J, Diaz-Sanchez M, Castilla A, Casares AD, Varela-Nieto I, et al: Hematotesticular barrier is altered from early stages of liver cirrhosis: effect of insulin-like growth factor 1. World J Gastroentero: WJG 2004, 10(17):2529-2534

229. Castilla-Cortazar I, Aliaga-Montilla MA, Salvador J, Garcia M, Delgado G, Gonzalez-Baron S, Quiroga J, Prieto J: Insulin-like growth factor-I restores the reduced somatostatinergic tone controlling growth hormone secretion in cirrhotic rats. Liver 2001, 21(6):405-409.

230. Garcia-Fernandez M, Castilla-Cortazar I, Diaz-Sanchez M, Navarro I, Puche JE, Castilla A, Casares AD, Clavijo E, Gonzalez-Baron S: Antioxidant effects of insulin-like growth factor-I (IGF-I) in rats with advanced liver cirrhosis. BMC Gastroenterol 2005, 5:7.

231. Muguerza B, Castilla-Cortazar I, Garcia M, Quiroga J, Santidrian S, Prieto J: Antifibrogenic effect in vivo of low doses of insulin-like growth factor-I in cirrhotic rats. Biochim Biophys Acta 2001, 1536(2-3):185-195.

232. Perez R, Garcia-Fernandez M, Diaz-Sanchez M, Puche JE, Delgado G, Conchillo M, Muntane J, Castilla-Cortazar I: Mitochondrial protection by low doses of insulin-like growth factor- I in experimental cirrhosis. World J Gastroentero: WJG 2008, 14(17):2731-2739.
233. Tutau F, Rodriguez-Ortigosa C, Puche JE, Juanarena N, Monreal I, Garcia Fernandez M, Clavijo E, Castilla A, Castilla-Cortazar I: Enhanced actions of insulin-like growth factor-I and interferon-alpha co-administration in experimental cirrhosis. Liver International: official journal of the International Association for the Study of the Liver 2009, 29(1):37-46.

234. Mirpuri E, Garcia-Trevijano ER, Castilla-Cortazar I, Berasain C, Quiroga J, Rodriguez-Ortigosa C, Mato JM, Prieto J, Avila MA: Altered liver gene expression in $\mathrm{CCl} 4$-cirrhotic rats is partially normalized by insulin-like growth factor-I. Int J Biochem Cell Biol 2002, 34(3):242-252.

235. Futterman $L G$, Lemberg $L$ : The framingham heart study: a pivotal legacy of the last millennium. American journal of critical care: an official publication, American Association of Critical-Care Nurses 2000, 9(2):147-151.

236. Fries JF: Aging, natural death, and the compression of morbidity. N Eng J Med 1980, 303(3):130-135.

237. Bartke A, Chandrashekar V, Dominici F, Turyn D, Kinney B, Steger R, Kopchick JJ: Insulin-like growth factor 1 (IGF-1) and aging: controversies and new insights. Biogerontology 2003, 4(1):1-8.

238. Weinert BT, Timiras PS: Invited review: theories of aging. J Appl Physiol 2003, 95(4):1706-1716.

239. Boveris A, Oshino N, Chance B: The cellular production of hydrogen peroxide. Biochem J 1972, 128(3):617-630.

240. Giulivi C, Boveris A, Cadenas E: Reactive oxygen species in biological systems: an interdisciplinary approach. In Edited by Gilbert D, Colton C. New York: Kluwer Academic/Plenum Publishers; 1999:77-102.

241. Van Raamsdonk JM, Meng Y, Camp D, Yang W, Jia X, Benard C, Hekimi S: Decreased energy metabolism extends life span in Caenorhabditis elegans without reducing oxidative damage. Genetics 2010, 185(2):559-571.

242. Hodge RD, D'Ercole AJ, O'Kusky JR: Insulin-like growth factor-I (IGF-I) inhibits neuronal apoptosis in the developing cerebral cortex in vivo. International journal of developmental neuroscience: the official journal of the International Society for Developmental Neuroscience 2007, 25(4):233-241.

243. Ye $P$, Xing $Y$, Dai $Z$, D'Ercole AJ: In vivo actions of insulin-like growth factor-I (IGF-I) on cerebellum development in transgenic mice: evidence that IGF-I increases proliferation of granule cell progenitors. Brain Res Dev Brain Res 1996, 95(1):44-54.

244. Chrysis D, Calikoglu AS, Ye P, D'Ercole AJ: Insulin-like growth factor-I overexpression attenuates cerebellar apoptosis by altering the expression of $\mathrm{Bcl}$ family proteins in a developmentally specific manner. J Neurosci 2001, 21(5):1481-1489.

245. Moverare-Skrtic S, Svensson J, Karlsson MK, Orwoll E, Ljunggren O, Mellstrom D, Ohlsson C: Serum insulin-like growth factor-I concentration is associated with leukocyte telomere length in a population-based cohort of elderly men. J Clin Endocrinol Metab 2009, 94(12):5078-5084.

246. Barbieri M, Paolisso G, Kimura M, Gardner JP, Boccardi V, Papa M, Hjelmborg JV, Christensen K, Brimacombe M, Nawrot TS, et al: Higher circulating levels of IGF-1 are associated with longer leukocyte telomere length in healthy subjects. Mech Ageing Dev 2009, 130(11-12):771-776.

247. Fitzpatrick AL, Kronmal RA, Gardner JP, Psaty BM, Jenny NS, Tracy RP Walston J, Kimura M, Aviv A: Leukocyte telomere length and cardiovascular disease in the cardiovascular health study. Am J Epidemiol 2007, 165(1):14-21.

248. Vasan RS, Demissie S, Kimura M, Cupples LA, Rifai N, White C, Wang TJ, Gardner JP, Cao X, Benjamin EJ, et al: Association of leukocyte telomere length with circulating biomarkers of the renin-angiotensin-aldosterone system: the framingham heart study. Circulation 2008, 117(9):1138-1144

249. Blakesley VA, Butler AA, Koval AP, Okubo Y, LeRoith D: IGF-1 receptor function: transducing the igf-1 signal into intracellular events. In The IGF system. Edited by Rosenfeld R, Roberts C. New Jersey: Humana Press; 1999:143-164.

250. White MF: The IRS-signalling system: a network of docking proteins that mediate insulin action. Mol Cell Biochem 1998, 182(1-2):3-11.

251. Skolnik EY, Batzer A, Li N, Lee CH, Lowenstein E, Mohammadi M, Margolis B, Schlessinger J: The function of GRB2 in linking the insulin receptor to Ras signaling pathways. Science 1993, 260(5116):1953-1955.

252. Cheatham B, Vlahos CJ Cheatham L, Wang L, Blenis J, Kahn CR. Phosphatidylinositol 3-kinase activation is required for insulin stimulation of pp 70 S6 kinase, DNA synthesis, and glucose transporter translocation. Mol Cell Biol 1994, 14(7):4902-4911.

253. Kohn AD, Summers SA, Birnbaum MJ, Roth RA: Expression of a constitutively active Akt Ser/Thr kinase in 3T3-L1 adipocytes stimulates 
glucose uptake and glucose transporter 4 translocation. J Biol Chem 1996, 271(49):31372-31378.

254. Zhang X, Gan L, Pan H, Guo S, He X, Olson ST, Mesecar A, Adam S, Unterman TG: Phosphorylation of serine 256 suppresses transactivation by FKHR (FOXO1) by multiple mechanisms. Direct and indirect effects on nuclear/cytoplasmic shuttling and DNA binding. J Biol Chem 2002, 277(47):45276-45284.

255. Van Der Heide LP, Hoekman MF, Smidt MP: The ins and outs of FoxO shuttling: mechanisms of FoxO translocation and transcriptional regulation. Biochem J 2004, 380(Pt 2):297-309.

256. Hribal ML, Nakae J, Kitamura T, Shutter JR, Accili D: Regulation of insulinlike growth factor-dependent myoblast differentiation by Foxo forkhead transcription factors. J Cell Biol 2003, 162(4):535-541.

257. Gilley J, Coffer PJ, Ham J: FOXO transcription factors directly activate bim gene expression and promote apoptosis in sympathetic neurons. J Cell Biol 2003, 162(4):613-622.

258. Martinez-Gac L, Marques M, Garcia Z, Campanero MR, Carrera AC: Control of cyclin G2 mRNA expression by forkhead transcription factors: novel mechanism for cell cycle control by phosphoinositide 3-kinase and forkhead. Mol Cell Biol 2004, 24(5):2181-2189.

259. Tran H, Brunet A, Grenier JM, Datta SR, Fornace AJ Jr, DiStefano PS, Chiang LW, Greenberg ME: DNA repair pathway stimulated by the forkhead transcription factor FOXO3a through the Gadd45 protein. Science 2002, 296(5567):530-534.

260. Brunet A, Sweeney LB, Sturgill JF, Chua KF, Greer PL, Lin Y, Tran H, Ross SE, Mostoslavsky R, Cohen HY, et al: Stress-dependent regulation of FOXO transcription factors by the SIRT1 deacetylase. Science 2004, 303(5666):2011-2015.

261. Facchini FS, Hua N, Abbasi F, Reaven GM: Insulin resistance as a predictor of age-related diseases. J Clin Endocrinol Metab 2001, 86(8):3574-3578.

262. DeFronzo RA, Ferrannini E: Insulin resistance. A multifaceted syndrome responsible for NIDDM, obesity, hypertension, dyslipidemia, and atherosclerotic cardiovascular disease. Diabetes Care 1991, 14(3):173-194.

263. Reaven GM: Banting lecture 1988. Role of insulin resistance in human disease. Diabetes 1988, 37(12):1595-1607.

264. Umegaki H: Neurodegeneration in diabetes mellitus. Adv Exp Med Biol 2012, 724:258-265

265. Bosco D, Plastino M, Cristiano D, Colica C, Ermio C, De Bartolo M, Mungari $P$, Fonte $G$, Consoli D, Consoli $A$, et al: Dementia is associated with insulin resistance in patients with Parkinson's disease. J Neurol Sci 2012, 315(1-2):39-43.

266. Longo VD: Linking sirtuins, IGF-I signaling, and starvation. Exp Gerontol 2009, 44(1-2):70-74

267. Rincon M, Muzumdar R, Atzmon G, Barzilai N: The paradox of the insulin/IGF1 signaling pathway in longevity. Mech Ageing Dev 2004, 125(6):397-403.

268. Barzilai N, Huffman DM, Muzumdar RH, Bartke A: The critical role of metabolic pathways in aging. Diabetes 2012, 61(6):1315-1322.

269. Tang BL: SIRT1, neuronal cell survival and the insulin/IGF-1 aging paradox. Neurobiol Aging 2006, 27(3):501-505.

270. Ungvari Z, Csiszar A: The emerging role of IGF-1 deficiency in cardiovascular aging: recent advances. The journals of gerontology Series A, Biological sciences and medical sciences 2012 67(6):599-610

271. Rosen T, Bengtsson BA: Premature mortality due to cardiovascular disease in hypopituitarism. Lancet 1990, 336(8710):285-288.

272. Laughlin GA, Barrett-Connor E, Criqui MH, Kritz-Silverstein D: The prospective association of serum insulin-like growth factor I (IGF-I) and IGF-binding protein-1 levels with all cause and cardiovascular disease mortality in older adults: the Rancho Bernardo Study. J Clin Endocrinol Metab 2004, 89(1):114-120.

273. Conti E, Carrozza C, Capoluongo E, Volpe M, Crea F, Zuppi C, Andreotti F: Insulin-like growth factor-1 as a vascular protective factor. Circulation 2004, 110(15):2260-2265

274. Sesti G, Sciacqua A, Cardellini M, Marini MA, Maio R, Vatrano M, Succurro E, Lauro R, Federici M, Perticone F: Plasma concentration of IGF-I is independently associated with insulin sensitivity in subjects with different degrees of glucose tolerance. Diabetes Care 2005, 28(1):120-125

275. Spallarossa P, Brunelli C, Minuto F, Caruso D, Battistini M, Caponnetto S, Cordera R: Insulin-like growth factor-I and angiographically documented coronary artery disease. Am J Cardiol 1996, 77(2):200-202.
276. Johnsen SP, Hundborg HH, Sorensen HT, Orskov H, Tjonneland A, Overvad K, Jorgensen JO: Insulin-like growth factor (IGF) I, -II, and IGF binding protein-3 and risk of ischemic stroke. J Clin Endocrinol Metab 2005, 90(11):5937-5941.

277. Vasan RS, Sullivan LM, D'Agostino RB, Roubenoff R, Harris T, Sawyer DB, Levy D, Wilson PW: Serum insulin-like growth factor I and risk for heart failure in elderly individuals without a previous myocardial infarction: the Framingham Heart Study. Ann Intern Med 2003, 139(8):642-648.

278. Conti E, Andreotti F, Sciahbasi A, Riccardi P, Marra G, Menini E, Ghirlanda G, Maseri A: Markedly reduced insulin-like growth factor- 1 in the acute phase of myocardial infarction. J Am Coll Cardiol 2001, 38(1):26-32.

279. Galderisi M, Caso P, Cicala S, De Simone L, Barbieri M, Vitale G, de Divitiis O, Paolisso G: Positive association between circulating free insulin-like growth factor-1 levels and coronary flow reserve in arterial systemic hypertension. Am J Hypertens 2002, 15(9):766-772.

280. Paolisso G, Ammendola S, Del Buono A, Gambardella A, Riondino M, Tagliamonte MR, Rizzo MR, Carella C, Varricchio M: Serum levels of insulinlike growth factor-I (IGF-I) and IGF-binding protein-3 in healthy centenarians: relationship with plasma leptin and lipid concentrations, insulin action, and cognitive function. J Clin Endocrinol Metab 1997, 82(7):2204-2209.

281. Bailey-Downs LC, Mitschelen M, Sosnowska D, Toth P, Pinto JT, Ballabh P, Valcarcel-Ares MN, Farley J, Koller A, Henthorn JC, et al: Liver-specific knockdown of IGF-1 decreases vascular oxidative stress resistance by impairing the Nrf2-dependent antioxidant response: a novel model of vascular aging. The journals of gerontology Series A, Biological sciences and medical sciences 2012, 67(4):313-329.

282. Li Q, Ceylan-Isik AF, Li J, Ren J: Deficiency of insulin-like growth factor 1 reduces sensitivity to aging-associated cardiomyocyte dysfunction. Rejuvenation Res 2008, 11(4):725-733.

283. Li Q, Wu S, Li SY, Lopez FL, Du M, Kajstura J, Anversa P, Ren J: Cardiacspecific overexpression of insulin-like growth factor 1 attenuates agingassociated cardiac diastolic contractile dysfunction and protein damage. Am J Physiol Heart Circ Physiol 2007, 292(3):H1398-H1403.

284. Li Q, Ren J: Influence of cardiac-specific overexpression of insulin-like growth factor 1 on lifespan and aging-associated changes in cardiac intracellular $\mathrm{Ca} 2+$ homeostasis, protein damage and apoptotic protein expression. Aging Cell 2007, 6(6):799-806.

285. Vinciguerra M, Santini MP, Claycomb WC, Ladurner AG, Rosenthal N: Local IGF-1 isoform protects cardiomyocytes from hypertrophic and oxidative stresses via SirT1 activity. Aging 2010, 2(1):43-62.

286. Ungvari Z, Gautam T, Koncz P, Henthorn JC, Pinto JT, Ballabh P, Yan H, Mitschelen M, Farley J, Sonntag WE, et al: Vasoprotective effects of life span-extending peripubertal GH replacement in Lewis dwarf rats. The journals of gerontology Series A, Biological sciences and medical sciences 2010, 65(11):1145-1156.

287. Urbanek K, Rota M, Cascapera S, Bearzi C, Nascimbene A, De Angelis A, Hosoda T, Chimenti S, Baker M, Limana F, et al: Cardiac stem cells possess growth factor-receptor systems that after activation regenerate the infarcted myocardium, improving ventricular function and long-term survival. Circ Res 2005, 97(7):663-673.

288. Torella D, Rota M, Nurzynska D, Musso E, Monsen A, Shiraishi I, Zias E, Walsh K, Rosenzweig A, Sussman MA, et al: Cardiac stem cell and myocyte aging, heart failure, and insulin-like growth factor- 1 overexpression. Circ Res 2004, 94(4):514-524.

289. Ungvari Z, Kaley G, de Cabo R, Sonntag WE, Csiszar A: Mechanisms of vascular aging: new perspectives. The journals of gerontology Series $A$ Biological sciences and medical sciences 2010, 65(10):1028-1041.

290. Li Y, Wu H, Khardori R, Song YH, Lu YW, Geng YJ: Insulin-like growth factor-1 receptor activation prevents high glucose-induced mitochondrial dysfunction, cytochrome-c release and apoptosis. Biochem Biophys Res Commun 2009, 384(2):259-264.

291. Rivard A, Fabre JE, Silver M, Chen D, Murohara T, Kearney M, Magner M, Asahara T, Isner JM: Age-dependent impairment of angiogenesis. Circulation 1999, 99(1):111-120.

292. Thum T, Hoeber S, Froese S, Klink I, Stichtenoth DO, Galuppo P, Jakob M, Tsikas D, Anker SD, Poole-Wilson PA, et al: Age-dependent impairment of endothelial progenitor cells is corrected by growth-hormone-mediated increase of insulin-like growth-factor-1. Circ Res 2007, 100(3):434-443. 
293. Csiszar A, Ungvari Z, Edwards JG, Kaminski P, Wolin MS, Koller A, Kaley G: Aging-induced phenotypic changes and oxidative stress impair coronary arteriolar function. Circ Res 2002, 90(11):1159-1166.

294. Csiszar A, Labinskyy N, Perez V, Recchia FA, Podlutsky A, Mukhopadhyay P, Losonczy G, Pacher P, Austad SN, Bartke A, et al: Endothelial function and vascular oxidative stress in long-lived GH/IGF-deficient Ames dwarf mice. Am J Physiol Heart Circ Physiol 2008, 295(5):H1882-H1894.

295. Cittadini A, Monti MG, Castiello MC, D’Arco E, Galasso G, Sorriento D, Saldamarco L, De Paulis A, Napoli R, laccarino G, et al: Insulin-like growth factor-1 protects from vascular stenosis and accelerates reendothelialization in a rat model of carotid artery injury. J Thromb Haemost: JTH 2009, 7(11):1920-1928.

296. Clemmons DR: Modifying IGF1 activity: an approach to treat endocrine disorders, atherosclerosis and cancer. Nat Rev Drug Discov 2007, 6(10):821-833.

297. Higashi Y, Sukhanov S, Anwar A, Shai SY, Delafontaine P: IGF-1, oxidative stress and atheroprotection. Trends Endocrin Met: TEM 2010, 21(4):245-254.

298. Ross R: Atherosclerosis-an inflammatory disease. N Eng J Med 1999, 340(2):115-126

299. Jeschke MG, Barrow RE, Herndon DN: Insulinlike growth factor I plus insulinlike growth factor binding protein 3 attenuates the proinflammatory acute phase response in severely burned children. Ann Surg 2000, 231(2):246-252.

300. National Cholesterol Education Program Expert Panel on Detection E, Treatment of High Blood Cholesterol in A: Third report of the national cholesterol education program (NCEP) expert panel on detection, evaluation, and treatment of high blood cholesterol in adults (adult treatment panel III) final report. Circulation 2002, 106(25):3143-3421.

301. Akanji AO, Smith RJ: The insulin-like growth factor system, metabolic syndrome, and cardiovascular disease risk. Metab Syndr Relat Disord 2012, 10(1):3-13.

302. Bideci A, Camurdan MO, Cinaz P, Dursun H, Demirel F: Serum zinc, insulinlike growth factor-I and insulin-like growth factor binding protein-3 levels in children with type 1 diabetes mellitus. J Pediatr Endocrinol Metab 2005, 18(10):1007-1011.

303. Simpson HL, Jackson NC, Shojaee-Moradie F, Jones RH, Russell-Jones DL, Sonksen PH, Dunger DB, Umpleby AM: Insulin-like growth factor I has a direct effect on glucose and protein metabolism, but no effect on lipid metabolism in type 1 diabetes. J Clin Endocrinol Metab 2004, 89(1):425-432.

304. Saukkonen T, Shojaee-Moradie F, Williams RM, Amin R, Yuen KC, Watts A, Acerini CL, Umpleby AM, Dunger DB: Effects of recombinant human IGF-I/ IGF-binding protein-3 complex on glucose and glycerol metabolism in type 1 diabetes. Diabetes 2006, 55(8):2365-2370.

305. Clemmons DR, Moses AC, McKay MJ, Sommer A, Rosen DM, Ruckle J: The combination of insulin-like growth factor I and insulin-like growth factorbinding protein-3 reduces insulin requirements in insulin-dependent type 1 diabetes: evidence for in vivo biological activity. J Clin Endocrinol Metab 2000, 85(4):1518-1524.

306. Kolaczynski JW, Caro JF: Insulin-like growth factor-1 therapy in diabetes: physiologic basis, clinical benefits, and risks. Ann Intern Med 1994, 120(1):47-55.

307. Paolisso G, Tagliamonte MR, Rizzo MR, Giugliano D: Advancing age and insulin resistance: new facts about an ancient history. Eur J Clin Invest 1999, 29(9):758-769.

308. Schini-Kerth VB: Dual effects of insulin-like growth factor-I on the constitutive and inducible nitric oxide (NO) synthase-dependent formation of NO in vascular cells. J Endocrinol Invest 1999, 22(5 Suppl):82-88.

309. Gomez JM, Maravall FJ, Gomez N, Navarro MA, Casamitjana R, Soler J: Interactions between serum leptin, the insulin-like growth factor-I system, and sex, age, anthropometric and body composition variables in a healthy population randomly selected. Clin Endocrinol 2003, 58(2):213-219.

310. Conti E, Andreotti F, Sestito A, Riccardi P, Menini E, Crea F, Maseri A, Lanza GA: Reduced levels of insulin-like growth factor- 1 in patients with angina pectoris, positive exercise stress test, and angiographically normal epicardial coronary arteries. Am J Cardiol 2002, 89(8):973-975.

311. Rasmussen MH, Hvidberg A, Juul A, Main KM, Gotfredsen A, Skakkebaek NE, Hilsted J, Skakkebae NE: Massive weight loss restores 24-hour growth hormone release profiles and serum insulin-like growth factor-l levels in obese subjects. J Clin Endocrinol Metab 1995, 80(4):1407-1415.
312. Twickler MT, Cramer MJ, Koppeschaar HP: Unraveling Reaven's syndrome $X$ : serum insulin-like growth factor-I and cardiovascular disease. Circulation 2003, 107(20):e190-e192. author reply e190-192.

313. Scheidegger KJ, James RW, Delafontaine P: Differential effects of low density lipoproteins on insulin-like growth factor-1 (IGF-1) and IGF-1 receptor expression in vascular smooth muscle cells. J Biol Chem 2000, 275(35):26864-26869.

314. Malik J, Stulc T, Wichterle D, Melenovsky V, Chytilova E, Lacinova Z, Marek J, Ceska R: Hyperlipidemia is associated with altered levels of insulin-like growth factor-I. Physiological research / Academia Scientiarum Bohemoslovaca 2008, 57(6):919-925.

315. Sandhu MS, Heald AH, Gibson JM, Cruickshank JK, Dunger DB, Wareham NJ: Circulating concentrations of insulin-like growth factor-I and development of glucose intolerance: a prospective observational study. Lancet 2002, 359(9319):1740-1745.

316. Efstratiadis G, Tsiaousis G, Athyros VG, Karagianni D, Pavlitou-Tsiontsi A, Giannakou-Darda A, Manes C: Total serum insulin-like growth factor-1 and C-reactive protein in metabolic syndrome with or without diabetes. Angiology 2006, 57(3):303-311.

317. Teramukai S, Rohan T, Eguchi H, Oda T, Shinchi K, Kono S: Anthropometric and behavioral correlates of insulin-like growth factor I and insulin-like growth factor binding protein 3 in middle-aged Japanese men. Am J Epidemiol 2002, 156(4):344-348

318. Trejo JL, Carro E, Nunez A, Torres-Aleman I: Sedentary life impairs selfreparative processes in the brain: the role of serum insulin-like growth factor-I. Rev Neurosci 2002, 13(4):365-374.

319. Unden AL, Elofsson S, Knox S, Lewitt MS, Brismar K: IGF-I in a normal population: relation to psychosocial factors. Clin Endocrinol 2002, 57(6):793-803.

320. Dandona P, Aljada A, Dhindsa S, Garg R: Insulin as an anti-inflammatory and antiatherosclerotic hormone. Clin Cornerstone 2003, (Suppl 4):S13-S20. PMID:14986904.

321. Gillespie CM, Merkel AL, Martin AA: Effects of insulin-like growth factor-I and LR3IGF-I on regional blood flow in normal rats. J Endocrinol 1997, 155(2):351-358.

322. Izhar U, Hasdai D, Richardson DM, Cohen P, Lerman A: Insulin and insulinlike growth factor-I cause vasorelaxation in human vessels in vitro. Coron Artery Dis 2000, 11(1):69-76.

323. Utriainen T, Nuutila P, Takala T, Vicini $P$, Ruotsalainen $U$, Ronnemaa $T$, Tolvanen T, Raitakari M, Haaparanta M, Kirvela O, et al: Intact insulin stimulation of skeletal muscle blood flow, its heterogeneity and redistribution, but not of glucose uptake in non-insulin-dependent diabetes mellitus. J Clin Invest 1997, 100(4):777-785.

324. Gasperi M, Castellano AE: Growth hormone/insulin-like growth factor I axis in neurodegenerative diseases. J Endocrinol Invest 2010, 33(8):587-591.

325. Torres-Aleman I: Targeting insulin-like growth factor-1 to treat Alzheimer's disease. Expert Opin Ther Targets 2007, 11(12):1535-1542.

326. Carro E, Trejo JL, Gerber A, Loetscher H, Torrado J, Metzger F, Torres-Aleman I: Therapeutic actions of insulin-like growth factor I on APP/PS2 mice with severe brain amyloidosis. Neurobiol Aging 2006, 27(9):1250-1257.

327. Cheng CM, Tseng V, Wang J, Wang D, Matyakhina L, Bondy CA: Tau is hyperphosphorylated in the insulin-like growth factor-I null brain. Endocrinology 2005, 146(12):5086-5091.

328. Akiyama H, Barger S, Barnum S, Bradt B, Bauer J, Cole GM, Cooper NR, Eikelenboom P, Emmerling M, Fiebich BL, et al: Inflammation and alzheimer's disease. Neurobiol Aging 2000, 21(3):383-421.

329. Miranda S, Opazo C, Larrondo LF, Munoz FJ, Ruiz F, Leighton F, Inestrosa NC: The role of oxidative stress in the toxicity induced by amyloid beta-peptide in alzheimer's disease. Prog Neurobio/ 2000, 62(6):633-648

330. Corbo M, Lunetta C, Magni P, Dozio E, Ruscica M, Adobbati L, Silani V: Free insulin-like growth factor (IGF)-1 and IGF-binding proteins-2 and -3 in serum and cerebrospinal fluid of amyotrophic lateral sclerosis patients. Eur J Neurol: the official journal of the European Federation of Neurological Societies 2010, 17(3):398-404.

331. Lunetta C, Serafini M, Prelle A, Magni P, Dozio E, Ruscica M, Sassone J, Colciago C, Moggio M, Corbo M, et al: Impaired expression of insulin-like growth factor-1 system in skeletal muscle of amyotrophic lateral sclerosis patients. Muscle Nerve 2012, 45(2):200-208. 
332. Kerkhoff H, Hassan SM, Troost D, Van Etten RW, Veldman H, Jennekens FG: Insulin-like and fibroblast growth factors in spinal cords, nerve roots and skeletal muscle of human controls and patients with amyotrophic lateral sclerosis. Acta Neuropathol 1994, 87(4):411-421.

333. Ozdinler PH, Macklis JD: IGF-I specifically enhances axon outgrowth of corticospinal motor neurons. Nat Neurosci 2006, 9(11):1371-1381.

334. Xiao Q, Zhao W, Beers DR, Yen AA, Xie W, Henkel JS, Appel SH: Mutant SOD1(G93A) microglia are more neurotoxic relative to wild-type microglia. J Neurochem 2007, 102(6):2008-2019.

335. Borasio GD, Robberecht W, Leigh PN, Emile J, Guiloff RJ, Jerusalem F, Silani V, Vos PE, Wokke JH, Dobbins T: A placebo-controlled trial of insulin-like growth factor-I in amyotrophic lateral sclerosis. European ALS/IGF-I study group. Neurology 1998, 51(2):583-586.

336. Lai EC, Felice KJ, Festoff BW, Gawel MJ, Gelinas DF, Kratz R, Murphy MF, Natter HM, Norris FH, Rudnicki SA: Effect of recombinant human insulin-like growth factor-I on progression of ALS. A placebo-controlled study. The north america ALS/IGF-I study group. Neurology 1997, 49(6):1621-1630.

337. Donnan GA, Fisher M, Macleod M, Davis SM: Stroke. Lancet 2008, 371(9624):1612-1623.

338. Murray CJ, Lopez AD: Mortality by cause for eight regions of the world: global burden of disease study. Lancet 1997, 349(9061):1269-1276.

339. De Smedt A, Brouns R, Uyttenboogaart M, De Raedt S, Moens M, Wilczak N, Luijckx GJ, De Keyser J: Insulin-like growth factor I serum levels influence ischemic stroke outcome. Stroke; a journal of cerebral circulation 2011 42(8):2180-2185.

340. Bulow B, Hagmar L, Mikoczy Z, Nordstrom CH, Erfurth EM: Increased cerebrovascular mortality in patients with hypopituitarism. Clin Endocrinol 1997, 46(1):75-81.

341. Sonntag WE, Lynch CD, Cooney PT, Hutchins PM: Decreases in cerebral microvasculature with age are associated with the decline in growth hormone and insulin-like growth factor 1. Endocrinology 1997, 138(8):3515-3520.

342. Sonntag WE, Lynch C, Thornton P, Khan A, Bennett S, Ingram R: The effects of growth hormone and IGF-1 deficiency on cerebrovascular and brain ageing. J Anat 2000, 197(Pt 4):575-585.

343. Lopez-Lopez C, LeRoith D, Torres-Aleman I: Insulin-like growth factor I is required for vessel remodeling in the adult brain. Proc Natl Acad Sci U S A 2004, 101(26):9833-9838.

344. Gonzalez C, Diaz F, Alonso A: Neuroprotective effects of estrogens: crosstalk between estrogen and intracellular insulin signalling. Infect Disord Drug Targets 2008, 8(1):65-67.

345. Garcia-Segura LM, Arevalo MA, Azcoitia I: Interactions of estradiol and insulin-like growth factor-I signalling in the nervous system: new advances. Prog Brain Res 2010, 181:251-272.

346. Fernandez AM, Torres-Aleman I: The many faces of insulin-like peptide signalling in the brain. Nat Rev Neurosci 2012, 13(4):225-239.

347. Ozdemir D, Baykara B, Aksu I, Kiray M, Sisman AR, Cetin F, Dayi A, Gurpinar T, Uysal N, Arda MN: Relationship between circulating IGF-1 levels and traumatic brain injury-induced hippocampal damage and cognitive dysfunction in immature rats. Neurosci Lett 2012, 507(1):84-89.

348. Muller AP, Fernandez AM, Haas C, Zimmer E, Portela LV, Torres-Aleman I: Reduced brain insulin-like growth factor I function during aging. $\mathrm{Mo} / \mathrm{Cell}$ Neurosci 2012, 49(1):9-12.

349. Gong X, Ma M, Fan X, Li M, Liu Q, Liu X, Xu G: Down-regulation of IGF-1/ IGF-1R in hippocampus of rats with vascular dementia. Neurosci Lett 2012, 513(1):20-24.

350. Zhao J, Harada N, Kurihara H, Nakagata N, Okajima K: Cilostazol improves cognitive function in mice by increasing the production of insulin-like growth factor-I in the hippocampus. Neuropharmacology 2010, 58(4-5):774-783.

351. Carmeli E, Coleman R, Reznick AZ: The biochemistry of aging muscle. Exp Gerontol 2002, 37(4):477-489.

352. Le Roith D, Bondy C, Yakar S, Liu JL, Butler A: The somatomedin hypothesis: 2001. Endocr Rev 2001, 22(1):53-74.

353. Florini JR, Ewton DZ, Coolican SA: Growth hormone and the insulin-like growth factor system in myogenesis. Endocr Rev 1996, 17(5):481-517.

354. Dennis RA, Przybyla B, Gurley C, Kortebein PM, Simpson P, Sullivan DH, Peterson CA: Aging alters gene expression of growth and remodeling factors in human skeletal muscle both at rest and in response to acute resistance exercise. Physiol Genomics 2008, 32(3):393-400.
355. Li M, Li C, Parkhouse WS: Age-related differences in the des IGF-Imediated activation of Akt-1 and p70 S6K in mouse skeletal muscle. Mech Ageing Dev 2003, 124(7):771-778.

356. Berryman DE, Christiansen JS, Johannsson G, Thorner MO, Kopchick JJ: Role of the GH/IGF-1 axis in lifespan and healthspan: lessons from animal models. Growth Horm IGF Res 2008, 18(6):455-471.

357. Bex M, Bouillon R: Growth hormone and bone health. Horm Res 2003, 60(Suppl 3):80-86.

358. Giustina A, Mazziotti G, Canalis E: Growth hormone, insulin-like growth factors, and the skeleton. Endocr Rev 2008, 29(5):535-559.

359. Sell C, Ptasznik A, Chang CD, Swantek J, Cristofalo VJ, Baserga R: IGF-1 receptor levels and the proliferation of young and senescent human fibroblasts. Biochem Biophys Res Commun 1993, 194(1):259-265.

360. Pfeilschifter J, Diel I, Pilz U, Brunotte K, Naumann A, Ziegler R: Mitogenic responsiveness of human bone cells in vitro to hormones and growth factors decreases with age. J Bone Miner Res: the official journal of the American Society for Bone and Mineral Research 1993, 8(6):707-717.

361. Hirschberg R, Adler S: Insulin-like growth factor system and the kidney: physiology, pathophysiology, and therapeutic implications. Am J Kidney Dis: the official journal of the National Kidney Foundation 1998, 31(6):901-919.

362. Rogers SA, Powell-Braxton L, Hammerman MR: Insulin-like growth factor I regulates renal development in rodents. Dev Genet 1999, 24(3-4):293-298.

363. Bridgewater DJ, Ho J, Sauro V, Matsell DG: Insulin-like growth factors inhibit podocyte apoptosis through the PI3 kinase pathway. Kidney Int 2005, 67(4):1308-1314.

364. Flyvbjerg A: Putative pathophysiological role of growth factors and cytokines in experimental diabetic kidney disease. Diabetologia 2000, 43(10):1205-1223.

365. Wang SN, LaPage J, Hirschberg R: Role of glomerular ultrafiltration of growth factors in progressive interstitial fibrosis in diabetic nephropathy. Kidney Int 2000, 57(3):1002-1014.

366. Kang BP, Urbonas A, Baddoo A, Baskin S, Malhotra A, Meggs LG: IGF-1 inhibits the mitochondrial apoptosis program in mesangial cells exposed to high glucose. Am J Physiol Renal Physiol 2003, 285(5):F1013-F1024.

367. Skjaerbaek C, Frystyk J, Orskov H, Kissmeyer-Nielsen P, Jensen MB, Laurberg S, Moller N, Flyvbjerg A: Differential changes in free and total insulin-like growth factor I after major, elective abdominal surgery: the possible role of insulin-like growth factor-binding protein-3 proteolysis. J Clin Endocrinol Metab 1998, 83(7):2445-2449.

368. Lang CH, Fan J, Frost RA, Gelato MC, Sakurai Y, Herndon DN, Wolfe RR: Regulation of the insulin-like growth factor system by insulin in burn patients. J Clin Endocrinol Metab 1996, 81(7):2474-2480.

369. Sermet-Gaudelus I, Souberbielle JC, Azhar I, Ruiz JC, Magnine P, Colomb V, Le Bihan C, Folio D, Lenoir G: Insulin-like growth factor I correlates with lean body mass in cystic fibrosis patients. Arch Dis Child 2003, 88(11):956-961.

370. Congote LF: Monitoring insulin-like growth factors in HIV infection and AIDS. Clin Chim Acta 2005, 361(1-2):30-53.

371. Clemmons DR: Clinical utility of measurements of insulin-like growth factor 1. Nat Clin Pract Endocrinol Metab 2006, 2(8):436-446.

372. Bondy CA, Underwood LE, Clemmons DR, Guler HP, Bach MA, Skarulis M: Clinical uses of insulin-like growth factor I. Ann Intern Med 1994, 120(7):593-601.

373. Ketelslegers JM, Maiter D, Maes M, Underwood LE, Thissen JP: Nutritional regulation of insulin-like growth factor-I. Metab Clin Exp 1995, 44(10 Suppl 4):50-57.

374. Pascal N, Amouzou EK, Sanni A, Namour F, Abdelmouttaleb I, Vidailhet M, Gueant JL: Serum concentrations of sex hormone binding globulin are elevated in kwashiorkor and anorexia nervosa but not in marasmus. Am J Clin Nutr 2002, 76(1):239-244.

375. Hwa V, Haeusler G, Pratt KL, Little BM, Frisch H, Koller D, Rosenfeld RG: Total absence of functional acid labile subunit, resulting in severe insulin-like growth factor deficiency and moderate growth failure. J Clin Endocrinol Metab 2006, 91(5):1826-1831.

376. Chernausek SD, Backeljauw PF, Frane J, Kuntze J, Underwood LE, Group GHISC: Long-term treatment with recombinant insulin-like growth factor (IGF)-I in children with severe IGF-I deficiency due to growth hormone insensitivity. J Clin Endocrinol Metab 2007, 92(3):902-910. 
377. Backeljauw PF, Underwood LE: Prolonged treatment with recombinant insulin-like growth factor-I in children with growth hormone insensitivity syndrome--a clinical research center study. GHIS Collaborative Group. J Clin Endocrinol Metab 1996, 81(9):3312-3317.

378. Ranke MB, Savage MO, Chatelain PG, Preece MA, Rosenfeld RG, Blum WF Wilton P: Insulin-like growth factor I improves height in growth hormone insensitivity: two years' results. Horm Res 1995,

44(6):253-264

379. Guevara-Aguirre J, Vasconez O, Martinez V, Martinez AL, Rosenbloom AL, Diamond FB Jr, Gargosky SE, Nonoshita L, Rosenfeld RG: A randomized, double blind, placebo-controlled trial on safety and efficacy of recombinant human insulin-like growth factor-I in children with growth hormone receptor deficiency. J Clin Endocrinol Metab 1995, 80(4):1393-1398.

380. Laron Z, Anin S, Klipper-Aurbach Y, Klinger B: Effects of insulin-like growth factor on linear growth, head circumference, and body fat in patients with Laron-type dwarfism. Lancet 1992, 339(8804):1258-1261.

381. Laron Z, Klinger B: Effect of insulin-like growth factor-I treatment on serum androgens and testicular and penile size in males with Laron syndrome (primary growth hormone resistance). Eur J Endocrinol 1998, 138(2):176-180.

382. Rosenbloom AL: Recombinant human insulin-like growth factor I (rhIGF-I) and rhIGF-l/rhlGF-binding-protein-3: new growth treatment options? J Pediatr 2007, 150(1):7-11.

383. Balhara B, Misra M, Levitsky LL: Recombinant human IGF-1 (insulin-like growth factor) therapy: where do we stand today? Indian J Pediatr 2012, 79(2):244-249

384. Rosenbloom AL: Mecasermin (recombinant human insulin-like growth factor I). Adv Ther 2009, 26(1):40-54

385. Ekstrom K, Carlsson-Skwirut C, Ritzen EM, Bang P: Insulin-like growth factor-I and insulin-like growth factor binding protein-3 cotreatment versus insulin-like growth factor-I alone in two brothers with growth hormone insensitivity syndrome: effects on insulin sensitivity, body composition and linear growth. Horm Res Paediatr 2011, 76(5):355-366.

386. Laron Z: Insulin-like growth factor-I treatment of children with Laron syndrome (primary growth hormone insensitivity). Pediatric endocrinology reviews: PER 2008, 5(3):766-771.

387. Midyett LK, Rogol AD, Van Meter QL, Frane J, Bright GM, Group MSS: Recombinant insulin-like growth factor (IGF)-I treatment in short children with low IGF-I levels: first-year results from a randomized clinical trial. J Clin Endocrinol Metab 2010, 95(2):611-619.

388. Bright GM, Rogers D, Gonzalez-Mendoza LF: Safety and efficacy of oncedaily rh/GF-1 treatment in prepubertal children with primary IGF-1 deficiency: results from a clinical trial, ICE 2008 meeting: 2008. Rio de Janeiro (Brazil): 2008.

389. Bright GM, Mendoza JR, Rosenfeld RG: Recombinant human insulin-like growth factor-1 treatment: ready for primetime. Endocrinol Metab Clin North Am 2009, 38(3):625-638.

390. Frystyk J, Freda P, Clemmons DR: The current status of IGF-I assays-a 2009 update. Growth Horm IGF Res 2010, 20(1):8-18.

391. Belobrajdic DP, Priebe IK, Forbes B, Flyvbjerg A, Chen JW, Cosgrove LJ, Frystyk J, Saunders IW: Assessing the potential usefulness of IGF-related peptides and adiponectin for predicting disease risk. Growth Horm IGF Res 2008, 18(3):198-204.

392. Brand-Miller JC, Liu V, Petocz P, Baxter RC: The glycemic index of foods influences postprandial insulin-like growth factor-binding protein responses in lean young subjects. Am J Clin Nutr 2005, 82(2):350-354

393. Juul A: Serum levels of insulin-like growth factor I and its binding proteins in health and disease. Growth Horm IGF Res 2003, 13(4):113-170.

394. Liao S, Guevara-Aguirre J, Bright G: Validation of a population pharmacokinetic (POP-PK) model for rh/GF-1 in humans, ENDO. San Diego (California): 2005.

395. Wilton P: Adverse events reported in KIGS. In Growth hormone therapy in pediatrics: 20 years of KIGS. Edited by Ranke MB, Price DA, Reiter EO. Basel, Switzerland: Karger; 2007:432-441.

396. Maneatis T, Baptista J, Connelly K, Blethen S: Growth hormone safety update from the national cooperative growth study. J Pediatr Endocrinol Metab 2000, 13(Suppl 2):1035-1044.

397. Klinger B, Laron Z: Three year IGF-I treatment of children with laron syndrome. J Pediatr Endocrinol Metab 1995, 8(3):149-158.
398. Ebeling PR, Jones JD, O'Fallon WM, Janes CH, Riggs BL: Short-term effects of recombinant human insulin-like growth factor I on bone turnover in normal women. J Clin Endocrinol Metab 1993, 77(5):1384-1387.

399. Conchillo M, de Knegt RJ, Payeras M, Quiroga J, Sangro B, Herrero Jl, Castilla-Cortazar I, Frystyk J, Flyvbjerg A, Yoshizawa C, et al: Insulin-like growth factor I (IGF-I) replacement therapy increases albumin concentration in liver cirrhosis: results of a pilot randomized controlled clinical trial. J Hepatol 2005, 43(4):630-636.

400. Laron Z, Ginsberg S, Lilos P, Arbiv M, Vaisman N: Long-term IGF-I treatment of children with laron syndrome increases adiposity. Growth Horm IGF Res 2006, 16(1):61-64.

401. McDonald A, Williams RM, Regan FM, Semple RK, Dunger DB: IGF-I treatment of insulin resistance. Eur J Endocrinol 2007, 157(Suppl 1):S51-S56.

402. Pollak M: The insulin and insulin-like growth factor receptor family in neoplasia: an update. Nat Rev Cancer 2012, 12(3):159-169.

403. Steuerman R, Shevah O, Laron Z: Congenital IGF1 deficiency tends to confer protection against post-natal development of malignancies. Eur J Endocrinol 2011, 164(4):485-489.

404. Nakae J, Kato M, Murashita M, Shinohara N, Tajima T, Fujieda K: Long-term effect of recombinant human insulin-like growth factor I on metabolic and growth control in a patient with leprechaunism. J Clin Endocrinol Metab 1998, 83(2):542-549.

405. de la Monte SM: Insulin resistance and alzheimer's disease. BMB Rep 2009, 42(8):475-481.

406. Lopez-Lopez C, Dietrich MO, Metzger F, Loetscher H, Torres-Aleman I: Disturbed cross talk between insulin-like growth factor I and AMPactivated protein kinase as a possible cause of vascular dysfunction in the amyloid precursor protein/presenilin 2 mouse model of alzheimer's disease. J Neurosci 2007, 27(4):824-831.

407. Mitchell JD, Wokke JH, Borasio GD: Recombinant human insulin-like growth factor I (rhIGF-I) for amyotrophic lateral sclerosis/motor neuron disease. Cochrane Database Syst Rev 2007, (4):CD002064. PMID: 17943766.

408. Switzer M, Rice J, Rice M, Hardin DS: Insulin-like growth factor-l levels predict weight, height and protein catabolism in children and adolescents with cystic fibrosis. J Pediatr Endocrinol Metab 2009, 22(5):417-424.

409. Jacob R, Barrett E, Plewe G, Fagin KD, Sherwin RS: Acute effects of insulinlike growth factor I on glucose and amino acid metabolism in the awake fasted rat. Comparison with insulin. J Clin Invest 1989, 83(5):1717-1723.

410. Meyer NA, Barrow RE, Herndon DN: Combined insulin-like growth factor-1 and growth hormone improves weight loss and wound healing in burned rats. J Trauma 1996, 41(6):1008-1012.

411. Haugaard SB, Andersen O, Hansen BR, Orskov H, Andersen UB, Madsbad S, Iversen J, Flyvbjerg A: Insulin-like growth factors, insulin-like growth factor-binding proteins, insulin-like growth factor-binding protein-3 protease, and growth hormone-binding protein in lipodystrophic human immunodeficiency virus-infected patients. Metab Clin Exp 2004, 53(12):1565-1573.

412. Flynn RS, Murthy KS, Grider JR, Kellum JM, Kuemmerle JF: Endogenous IGF-I and alphaVbeta3 integrin ligands regulate increased smooth muscle hyperplasia in stricturing Crohn's disease. Gastroenterology 2010, 138(1):285-293.

413. Fletcher L, Kohli S, Sprague SM, Scranton RA, Lipton SA, Parra A, Jimenez DF, Digicaylioglu M: Intranasal delivery of erythropoietin plus insulin-like growth factor-I for acute neuroprotection in stroke. Laboratory investigation. J Neurosurg 2009, 111(1):164-170.

414. Murillo-Cuesta S, Rodriguez-de la Rosa L, Cediel R, Lassaletta L, Varela-Nieto I: The role of insulin-like growth factor-I in the physiopathology of hearing. Front Mol Neurosci 2011, 4:11.

415. Abdulle AM, Gillett MP, Abouchacra S, Sabri SM, Rukhaimi MA, Obineche EN, Singh J: Low IGF-1 levels are associated with cardiovascular risk factors in haemodialysis patients. Mol Cell Biochem 2007, 302(1-2):195-201.

416. Boonen S, Rosen C, Bouillon R, Sommer A, McKay M, Rosen D, Adams S, Broos P, Lenaerts J, Raus J, et al: Musculoskeletal effects of the recombinant human IGF-I/IGF binding protein-3 complex in osteoporotic patients with proximal femoral fracture: a double-blind, placebocontrolled pilot study. J Clin Endocrinol Metab 2002, 87(4):1593-1599.

417. Rubin CD, Reed B, Sakhaee K, Pak CY: Treating a patient with the Werner syndrome and osteoporosis using recombinant human insulin-like growth factor. Ann Intern Med 1994, 121(9):665-668.

418. De Ravin SS, Shum E, Zarember KA, Rezvani G, Rosenfeld RG, Stratakis CA, Malech HL: Short stature in partially corrected X-linked severe combined 
immunodeficiency-suboptimal response to growth hormone. J Pediatr Endocrinol Metab 2008, 21(11):1057-1063.

419. Heatwole CR, Eichinger KJ, Friedman DI, Hilbert JE, Jackson CE, Logigian EL, Martens WB, McDermott MP, Pandya SK, Quinn C, et al: Open-label trial of recombinant human insulin-like growth factor $1 /$ recombinant human insulin-like growth factor binding protein 3 in myotonic dystrophy type 1. Arch Neurol 2011, 68(1):37-44.

420. Misra M, McGrane J, Miller KK, Goldstein MA, Ebrahimi S, Weigel T, Klibansk A: Effects of rhIGF-1 administration on surrogate markers of bone turnover in adolescents with anorexia nervosa. Bone 2009, 45(3):493-498.

421. Hollis ER II, Lu P, Blesch A, Tuszynski MH: IGF-I gene delivery promotes corticospinal neuronal survival but not regeneration after adult CNS injury. Exp Neurol 2009, 215(1):53-59.

422. Hansen-Pupp I, Engstrom E, Niklasson A, Berg AC, Fellman V, Lofqvist C, Hellstrom A, Ley D: Fresh-frozen plasma as a source of exogenous insulin-like growth factor-l in the extremely preterm infant. J Clin Endocrinol Metab 2009, 94(2):477-482

423. Katz LE, Ferry RJ Jr, Stanley CA, Collett-Solberg PF, Baker L, Cohen P: Suppression of insulin oversecretion by subcutaneous recombinant human insulin-like growth factor I in children with congenital hyperinsulinism due to defective beta-cell sulfonylurea receptor. $J$ Clin Endocrinol Metab 1999, 84(9):3117-3124.

424. Diez-Caballero F, Castilla-Cortazar I, Garcia-Fernandez M, Puche JE, DiazSanchez M, Casares AD, Aliaga-Montilla MA, Rodriguez-Borrajo C, GonzalezBaron S: Little effects of insulin-like growth factor-I on testicular atrophy induced by hypoxia. BMC Urol 2006, 6:4.

425. Smith LE, Shen W, Perruzzi C, Soker S, Kinose F, Xu X, Robinson G, Driver S, Bischoff J, Zhang B, et al: Regulation of vascular endothelial growth factor-dependent retinal neovascularization by insulin-like growth factor1 receptor. Nat Med 1999, 5(12):1390-1395.

doi:10.1186/1479-5876-10-224

Cite this article as: Puche and Castilla-Cortázar: Human conditions of insulin-like growth factor-I (IGF-I) deficiency. Journal of Translational Medicine 2012 10:224

\section{Submit your next manuscript to BioMed Central and take full advantage of:}

- Convenient online submission

- Thorough peer review

- No space constraints or color figure charges

- Immediate publication on acceptance

- Inclusion in PubMed, CAS, Scopus and Google Scholar

- Research which is freely available for redistribution 